Winter 2021

\title{
The Zoning Straitjacket: The Freezing of American Neighborhoods of Single-Family Houses
}

Robert Ellickson

Yale University, robert.ellickson@yale.edu

Follow this and additional works at: https://www.repository.law.indiana.edu/ilj

Part of the Housing Law Commons, Land Use Law Commons, Law and Politics Commons, and the State and Local Government Law Commons

\section{Recommended Citation}

Ellickson, Robert (2021) "The Zoning Straitjacket: The Freezing of American Neighborhoods of SingleFamily Houses," Indiana Law Journal: Vol. 96 : Iss. 2 , Article 2.

Available at: https://www.repository.law.indiana.edu/ilj/vol96/iss2/2

This Article is brought to you for free and open access by the Law School Journals at Digital Repository @ Maurer Law. It has been accepted for inclusion in Indiana Law Journal by an authorized editor of Digital Repository @ Maurer Law. For more information, please contact rvaughan@indiana.edu.

\section{$\Psi$}

JEROME HALL LAW LIBRARY

INDIANA UNIVERSITY

Maurer School of Law
Bloomington 


\title{
THE ZONING STRAITJACKET: THE FREEZING OF AMERICAN NEIGHBORHOODS OF SINGLE-FAMILY HOUSES
}

\author{
ROBERT C. ELLICKSON*
}

Municipal zoning practices profoundly shape urban life in the United States. In regions such as Silicon Valley, regulatory barriers to residential construction have helped raise house prices to roughly ten times the national median. These astronomic prices have prompted some households to move to places, such as Texas, where housing is far cheaper. I have been engaged in an empirical study of zoning practices in Silicon Valley, Greater New Haven, and Greater Austin. This Article presents one of my central findings, induced from those metropolitan areas and elsewhere: local zoning politics typically freezes land uses in an established neighborhood of detached houses. The consequences are profound. Single-family neighborhoods constitute a solid majority of urban land in the United States. Within these frozen neighborhoods, real estate markets cannot respond to changes in supply and demand conditions.

This Article marshals a variety of evidence to prove that the zoning straitjacket exists. It also discusses possible exceptions to it. The most plausible is proximity to a newly opened transit node, an event that may transform zoning outcomes, even in a neighborhood of houses. Building on the work of others, notably William Fischel, I explore the dynamics of local zoning politics. The goal is to develop an overarching theory that is consistent with the larger study's three basic empirical findings: that suburbs in Greater Austin, Texas, are relatively pro-growth; that, even in Greater Austin, zoning policies freeze land uses in established neighborhoods of detached houses; and that the opening of a new transit node sometimes can loosen the zoning straitjacket.

* Walter E. Meyer Professor Emeritus of Property and Urban Law and Professorial Lecturer in Law, Yale Law School. The Oscar M. Ruebhausen Fund at Yale Law School generously provided support. Thanks to Eric Biber, Chris Elmendorf, Lee Anne Fennell, Owen Jones, David Schleicher, and Lior Strahilevitz for comments, and to Brian Chen for exceptional research assistance. Thanks also to participants in the University of Chicago Law School's Law-and-Economics Workshop. The author is willing to provide access to all underlying data. 


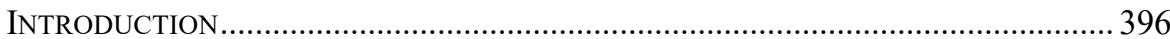

I. The Zoning Straituacket in Neighborhoods of Detached Houses .......... 401

A. SUPPORTIVE EVIDENCE FROM FOUR FAMOUS SUBURBS ........................... 401

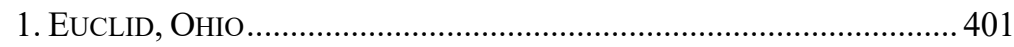

2. THE LEVITTOWNS ........................................................................ 403

B. Straitjacketed Single-Family Neighborhoods in ThreE

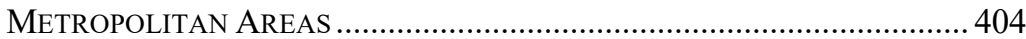

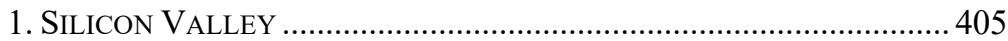

2. GREATER NEW HAVEN ................................................................ 407

3. GREATER AUSTIN ............................................................................ 408

C. Exceptions to the Straitjacket: Neighborhoods NeAR a NeW

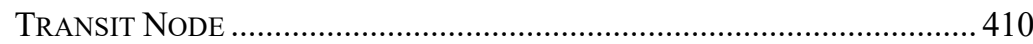

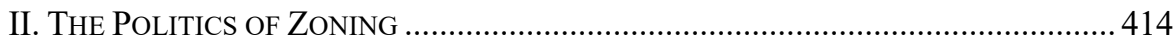

A. CURRent Theories of Zoning Politics ............................................. 415

B. Why Are Austin Suburbs Relatively Pro-Growth?..................... 418

C. Why Homeowners Typically CAN FreEZE Zoning, Even in Greater

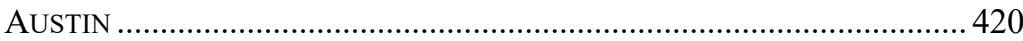

1. PSYCHOLOGY: StATUS QUO BIAS ................................................ 420

2. SOCIOlOGY: ESTEEM AND DisESTEEM IN THE EYES OF NEIGHBORS425

3. NORMS OF DistRIBUTIVE JUSTICE ............................................. 425

D. Proximity to a Transit Node May Flip Zoning Politics Toward

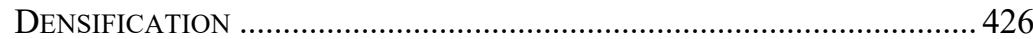

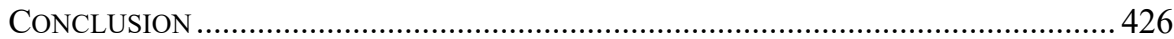

\section{INTRODUCTION}

Recall the neighborhood where you spent your childhood. For most Americans, it would have been a neighborhood of detached single-family houses. ${ }^{1}$ The thesis of this Article is simple: if you were to visit that same neighborhood decades from now, it would remain virtually unchanged. One reason is economic: structures typically are built to last. But a second reason, and the focus of this Article, is the impact of law. The politics of local zoning, a form of public land use regulation that has become ubiquitous in the United States during the past century, almost invariably works to freeze land uses in neighborhoods of houses.

Attorneys associate the U.S. practice of municipal zoning with a watershed case decided by the Supreme Court in 1926, Village of Euclid v. Ambler Realty Co. ${ }^{2}$ Ohio District Judge David Westenhaver conducted the trial, a property owner's challenge

1. The 2017 American Housing Survey reported that $63.2 \%$ of U.S. housing units were single-family detached houses. An additional $5.5 \%$ were mobile homes and $7.4 \%$, singlefamily attached. American Housing Survey 2017 National General Housing Data, U.S. Census BurEaU, https://www.census.gov/programs-surveys/ahs/data/interactive /ahstablecreator.html?s_areas $=00000 \&$ s_year $=2017 \&$ s_tablename $=$ TABLE1\&s_bygroup $1=$ $3 \&$ s_bygroup2 $=18 \&$ s_filtergroup1=1\&s_filtergroup2 $=1$ [https://perma.cc/UK6C-G6A9].

2. 272 U.S. 365 (1926), rev'g Ambler Realty Co. v. Village of Euclid, 297 F. 307 (N.D. Ohio, 1924). 
to the validity of a zoning ordinance of a suburb just east of Cleveland. Euclid's zoning map had depicted various zones, and the Village's ordinance regulated permissible land uses, lot sizes, and building bulks in each of them. Judge Westenhaver ultimately held that the ordinance violated, among other constitutional provisions, the Due Process Clause of the Fourteenth Amendment. The Supreme Court, in a decision that has become of a staple of American legal education, reversed. ${ }^{3}$ I focus less on Judge Westenhaver's legal analysis than on his conception of zoning politics. His opinion stated, "The plain truth is that the true object of the ordinance in question is to place all the property in an undeveloped area of 16 square miles [that is, all of Euclid] in a strait-jacket." " Judge Westenhaver wrongly forecast the outcomes of local zoning politics. In an undeveloped neighborhood, Not-In-MyBackyard (NIMBY) forces are relatively weak. ${ }^{5}$ But in a developed neighborhood of detached houses, "straitjacket" perfectly describes the usual upshot of zoning controls. ${ }^{6}$ This Article draws on the zoning histories of various municipalities, including the City of Euclid's, to support this central thesis.

The zoning straitjacket binds a large majority of urban land in the United States. Los Angeles and Chicago, two of the nation's densest central cities, permit the building of only a detached house on, respectively, $75 \%$ and $79 \%$ of the areas they zone for residential use. ${ }^{7}$ In suburban areas, the percentage typically is far higher. In a companion study of zoning practices of thirty-seven suburbs in Silicon Valley, Greater New Haven, and Greater Austin, I found that, in the aggregate, these municipalities had set aside $91 \%$ of their residentially zoned land (71\% of their total land area) exclusively for detached houses. ${ }^{8}$ For many local officials, only a detached

3. For a thorough historical account, see Michael Allan Wolf, The Zoning of AMERICA: EuCliD V. AMBLER (2008).

4. Ambler, $297 \mathrm{~F}$. at 316. The judge overestimated the village's land area. In 1924, the Village of Euclid had a land area of roughly eleven square miles. After minor annexations by various neighbors, including the City of Cleveland, in 2019 Euclid's land area had fallen to 10.6 square miles. See Cleveland Annexation Map (illustration), on WikimediA, https://upload.wikimedia.org/wikipedia/commons/9/93/Cleveland_Annexation_Map_4 -Color_Final.png [https://perma.cc/34C8-MNU3].

5. On the psychology of NIMBYism, see infra note 162.

6. The inimitable Jane Jacobs came up with another apt analogy: the taxidermy of urban space. Anika Singh Lemar, Zoning as Taxidermy: Neighborhood Conservation Districts and the Regulation of Aesthetics, 90 IND. L.J. 1525, 1539 n.91 (2015) (citing JANE JACOBS, THE Death ANd Life of Great American Cities 373 (Vintage Books ed. 1992) (1961)).

7. Emily Badger \& Quoctrung Bui, Cities Start to Question an American Ideal: A House with a Yard on Every Lot, N.Y. Times: THE UpSHOt (June 18, 2019), https://www.nytimes.com /interactive/2019/06/18/upshot/cities-across-america-question-single-family-zoning.html [https://perma.cc/HM4P-YYMJ]. The authors assert that the lowest percentage, 15\%, was in New York City, the nation's densest city. Id.

8. Robert C. Ellickson, Zoning and the Cost of Housing: Evidence from Silicon Valley, Greater New Haven, and Greater Austin, 44 CARDOZO L. REv (forthcoming) (manuscript at 15-16). (I have posted a draft of this article on SSRN. The page numbers in this crossreference, and those hereafter, indicate pages in the version posted at https://papers.ssrn.com /sol3/papers.cfm?abstract_id=3472145 [https://perma.cc/2ZT7-2GXC].) In the three named metros, localities in Silicon Valley were the least likely to zone exclusively for single-family detached houses. $I d$. at $16 \mathrm{n} .43$. Yet even they placed $85 \%$ of their residential land in zones 
house seems to satisfy the American Dream of homeownership. A townhouse or condo does not suffice. Planners in other developed nations largely disagree. They are far more likely to permit the mixing of different types of dwellings in the same neighborhood. ${ }^{9}$

The single-family zone, ubiquitous in American cities and suburbs, is popular because it generates real benefits. It may protect homeowners' property values and enhance their peace of mind. On balance, however, some single-family zones, perhaps a large fraction, inflict net social harm. A handful of professors at planning schools have begun to urge abolition of the zone. ${ }^{10}$ Absent overly strict regulation, suppliers of goods in a market economy are able to adapt to changes in supply and demand. The freezing of land uses in a broad swath of urban America prevents housing developers from responding to changes in consumer tastes about where and how to live. Especially in West Coast and Northeastern states, the zoning straitjacket has helped stifle the building of denser housing. ${ }^{11}$ In 2019, house prices in Silicon Valley had risen to ten times the national median, partly in response to the tightness of its municipalities' zoning. ${ }^{12}$ The freezing of land uses also misallocates the national labor force. ${ }^{13}$ Prior to 1970 , the temperate parts of California were magnets for interstate migrants. Since 2000, there has been a net outflow of households from California to sweltering Texas, a change that worsens the nation's carbon footprint. The zoning straitjacket also contributes to urban sprawl and automobile dependence. It can impair a metropolitan area's attainment of agglomeration efficiencies - the net advantages individuals obtain from living near others. ${ }^{14}$ For many observers, the most grievous national cost of current zoning practices is the worsening of the life chances of American children living in relatively poor households. ${ }^{15}$

that permitted only that use. Id. Mountain View, the Silicon Valley suburb least so inclined, restricts $52 \%$ of its residentially zoned land solely to detached houses. Id.

9. Sonia A. Hirt, Zoned in the USA: The Origins And IMPliCATIONS OF AmericAN LAND-USE REGULATION 6-7, 17-25 (2014).

10. In 2020, in a sharp break with prior orthodoxy, the leading U.S. planning journal published two articles calling for abolition of the traditional single-family zone. Michael Manville, Paavo Monkkonen \& Michael Lens, It's Time to End Single-Family Zoning, 86 J. Am. Plan. Ass'N 106 (2020); Jake Wegmann, Death to Single-Family Zoning . . . and New Life to the Missing Middle, 86 J. AM. PLAN. Ass'N 113 (2020). The same issue included brief responses by skeptics. See, e.g., Paul Mogush \& Heather Worthington, The View from Minneapolis: Comments on "Death to Single-Family Zoning” and "It's Time to End SingleFamily Zoning,” 86 J. AM. PlanNING Ass’N 120 (2020).

11. See Joseph Gyourko, Albert Saiz \& Anita Summers, A New Measure of the Local Regulatory Environment for Housing Markets: The Wharton Residential Land Use Regulatory Index, 45 URB. STUD. 693, 711, 713 (2008) (providing data on regulatory patterns at the state and metropolitan levels).

12. Prices derived in April 2019 from the Zillow Home Value Index. Ellickson, supra note 8 , at 5 n.5.

13. See Peter Ganong \& Daniel Shoag, Why Has Regional Income Convergence in the U.S. Declined?, 102 J. Urb. Econ. 76, 80-83 (2017).

14. See Ellickson, supra note 8, at 91-92.

15. See Raj Chetty, Nathaniel Hendren \& Lawrence F. Katz, The Effects of Exposure to Better Neighborhoods on Children: New Evidence from the Moving to Opportunity Experiment, 106 AM. ECON. REV. 855, 855-57 (2016) (finding that children under age thirteen 
Three initial clarifications of the scope of the straitjacket thesis are in order. First, in a neighborhood of houses, zoning policies typically do not bar a homeowner from remodeling a detached house, or even from razing it to build another. ${ }^{16}$ In most urban areas, however, local zoning politics almost never allows a landowner to replace a house with a denser residential use such as a duplex, set of townhouses, or an apartment building. ${ }^{17}$ Second, although I restrict the thesis to neighborhoods of detached houses (where it best applies), opposition to residential change undoubtedly extends more broadly. ${ }^{18}$ Residents of townhouses, for example, are likely to oppose the erection of somewhat taller multifamily structures. ${ }^{19}$ Third, in most U.S. regions, the straitjacket has become tighter over time. In the 1920 s, shortly after the advent of zoning, suburbs such as Euclid, Ohio, and Palo Alto, California, had begun to freeze single-family zones in neighborhoods where streets had already been laid out. ${ }^{20}$ But the straitjacket likely became tighter in many U.S. regions roughly around $1970 .^{21}$ The rise of the environmental movement seems to have heightened urbanites' preferences for policies that perpetuate familiar land uses. Palo Alto, whose policies had been pro-growth prior to 1965 , during the next decade came to be controlled by anti-growth Residentialists. ${ }^{22}$ In Palo Alto, this transformation led not only to stricter zoning of undeveloped land, but also to ever-tighter straitjackets in existing singlefamily neighborhoods.

This Article frequently refers, particularly in footnotes, to a companion piece. ${ }^{23}$ There I compare the zoning practices of local governments in the three chosen metropolitan areas. The current Article, however, is mostly longitudinal, not cross-

who grow up in predominantly poor neighborhoods have fewer life chances).

16. Zoning provisions typically allow the owner of a house not in a historic district to raze the existing use, provided the owner continues to comply with applicable use and bulk restrictions. In a covenanted community, as well as a historic district, an owner's options commonly are more limited.

17. A few jurisdictions, including Minneapolis and the state of Oregon, have taken steps to abolish the single-family zone. See infra note 100 and accompanying text. Some states also compel localities to permit the construction of accessory dwelling units (ADUs) in singlefamily districts. Margaret F. Brinig \& Nicole Stelle Garnett, A Room of One's Own? Accessory Dwelling Unit Reforms and Local Parochialism, 45 URB. LAw. 519, 520-21 (2013).

18. See infra text accompanying notes $172-75$.

19. E.g., Roderick M. Hills, Jr. \& David N. Schleicher, Balancing the "Zoning Budget," 62 CASE W. RSRV. L. REV. 81, 83-85 (2011) (describing how owners of townhouses supported the rollback of permitted heights of midrise apartments in Brooklyn's Carroll Gardens neighborhood).

20. See infra text accompanying notes 33-36, 49-58.

21. See, e.g., William A. Fischel, The Rise of the Homevoters: How the Growth Machine Was Subverted by OPEC and Earth Day, in EVIDENCE AND INNOVATION IN Hous. LAW \& PoliCY 17 (Lee Anne Fennell \& Benjamin J. Keys eds., 2017). In what may not have been entirely a coincidence, around 1970 the rate of U.S. economic growth began to slow. See Robert J. Gordon, The Rise and Fall of American Growth: The U.S. Standard of Living SinCE THE CiVIL WAR (2016). Gordon primarily attributes the decline to a falloff in great inventions. He notes, however, that excessive land use regulations may also have contributed. See id. at 649.

22. Ellickson, supra note 8, at 38, 44 .

23. Id. 
sectional. It stresses change - or, in this instance, lack of change - in legal rules over time. ${ }^{24}$ In some instances in this Article, I refer to the contents of decades-old zoning maps and ordinances, documents that local planning offices generously provided. ${ }^{25}$

A brief roadmap may be of help. Part I is devoted to proof of this Article's central thesis: that zoning ordinances straitjacket land uses in established U.S. neighborhoods of detached houses. ${ }^{26}$ I invoke a variety of seldom-cited sources to support this thesis. The freeze exists not only in ritzy suburbs, but also less prosperous ones, and even in pro-growth Texas. Part I ends with an exploration of possible exceptions to the straitjacket. When a new transit node comes into being, a rezoning to allow residential densification nearby may become politically feasible.

Zoning policies are political outcomes. Part II therefore is devoted to the dynamics of local zoning politics, the subject of a growing literature. Current theories of politics, I assert, pay too little attention to the roles of ideology, sorting by ideology, and, in particular, behavioral psychology. Status quo bias plays an enormous role in zoning politics.

As an example of a neighborhood ripe for residential densification, this Article, like its companion, commonly invokes Professorville, a Palo Alto neighborhood of mostly single-family detached houses. Professorville is centrally located. It lies about a half mile from both downtown Palo Alto and a Caltrain station that enables commuting to San Francisco and San Jose. In about 1980, the National Register of Historic Places recognized part of Professorville as a historic district. In 1993, Palo Alto unilaterally doubled, for municipal purposes, the size of the Professorville district. As a result, less than half of the houses within its larger boundary can individually claim historic distinction. ${ }^{27}$ Absent zoning constraints, developers likely would have bought up many Professorville lots, razed their current structures, and replaced them with denser residential uses such as townhouses or low-rise apartments. This is exactly what the straitjacket has made impossible. ${ }^{28}$

24. An alternative longitudinal analysis would have entailed the study, in specific urban areas, of aerial photographs of varying vintages. For that sort of work, geographers are more likely than legal scholars to have the pertinent skill set. For the potential of this approach, see John Hasse, John Reiser \& Alexander Pichacz, Evidence of Persistent Exclusionary Effects of Land Use Policy Within Historic and Projected Development Patterns in New Jersey: A Case Study of Monmouth and Somerset Counties (June 2011).

25. Most municipal planning departments post online versions of both their current zoning map and zoning ordinance, but understandably presume that there is little interest in prior versions of these documents.

26. Local government record keeping is erratic, to put it gently. The City Clerk of Palo Alto, an upscale Silicon Valley suburb, stated that the city no longer has a copy of Ordinance 172, its first zoning ordinance, adopted on Aug. 16, 1918. Email from Beth Minor, City Clerk, City of Palo Alto, Cal., to author (Dec. 30, 2018, 14:47 PST) (on file with author); see also infra note 75 .

27. Ellickson, supra note 8, at 12 n.32.

28. The U.S. law of real property traditionally has included doctrines designed to keep land markets dynamic. Among them have been the Rule Against Perpetuities and the Rule Against Restraints on Alienation. See Richard R. W. Brooks \& CAROL M. Rose, SAVIng THE Neighborhood: Racially Restrictive Covenants, Law, and Social Norms 73-78 (2013). 


\section{The Zoning Straitjacket in Neighborhoods of Detached Houses}

This Part provides evidence that zoning politics virtually always freezes land uses in already developed single-family neighborhoods. There are exceptions to the zoning straitjacket, however, and the Part's concluding section turns to them.

Two sources strongly support the facial plausibility of the straitjacket thesis. Neither has been previously cited in the legal literature. First, a Massachusetts agency found that more than $99.7 \%$ of the state's land in single-family use in 1970 remained in single-family use in 1999, almost thirty years later. ${ }^{29}$ Second, in an invaluable blog post, Issi Romem, a recently minted Ph.D. economist, tracked housing construction in all major U.S. metropolitan areas between 1940 and $2016 .{ }^{30}$ In recent decades, Romem found that most suburban areas had become "dormant"-his term for straitjacketed - while a few have been "pockets of dense construction." The authors of both these studies are fully aware that local zoning and planning practices have led to the rigidities that they document. But neither offers direct evidence of the history of the evolution of land use controls. The next two Subparts tackle that task, marshaling support from selected suburbs in seven different states.

\section{A. Supportive Evidence from Four Famous Suburbs}

\section{Euclid, Ohio}

I first induced the reality of the zoning straitjacket from studying the zoning history of the City of Euclid, site of the landmark judicial decision. I later discovered that Jonathan Levine had previously expounded the same thesis. ${ }^{31}$ I salute him. Levine's book, however, placed little emphasis on the straitjacket finding, and no author of a law journal article has associated him with the idea. ${ }^{32}$

The City of Euclid, a Cleveland suburb on Lake Erie, was a mere "village" during its day in the sun in 1926. On account of its fame, Euclid's 1922 zoning map and

29. Jonathan Levine, Zoned Out: Regulation, Markets, and Choices in TRANSPortation AND Metropolitan Land Use 78 (2006) (citing a 2002 database of the Massachusetts Executive Office of Environmental Affairs, available at https://www.mass.gov /mgis/ [https://perma.cc/XX6J-2U59]). The Massachusetts data actually suggest even less change. As Levine describes, much of the change occurred in the Town of Sudbury, where low-density, single-family neighborhoods were transformed into medium-density, singlefamily neighborhoods. Id.

30. Issi Romem, America's New Metropolitan Landscape: Pockets of Dense Construction in a Dormant Suburban Interior, BuILDZoom (Feb. 1, 2018), https://www.buildzoom.com /blog/pockets-of-dense-construction-in-a-dormant-suburban-interior [https://perma.cc/NJS7 -SG9K].

31. LeVINE, supra note 29, at 76-81, $204 \mathrm{n} .1$ (2006). Levine is a professor at the University of Michigan's Taubman College of Architecture and Urban Planning.

32. Other precursors worthy of note include Christopher S. Elmendorf, Beyond the Double Veto: Land Use Plans as Preemptive Intergovernmental Contracts, 71 HASTINGS L.J. 79, 88-89 (2019) (briefly asserting a "density stasis in extant residential neighborhoods"), and Jonathan Rothwell \& Douglas S. Massey, The Effect of Density Zoning on Racial Segregation in U.S. Urban Areas, 44 URB. AfF. REv. 779, 790 (2009) (showing stability of localities' zoning regulations between 1988 and 2003). 
ordinance are among the few from that era available online. ${ }^{33}$ Both documents illustrate the potency of path dependence in zoning practices. In 1922, the Village of Euclid called its basic single-family detached zone U1. Almost a century later, the 2020 Euclid ordinance retained that exact label. ${ }^{34}$ In 1922, the Village required a minimum house lot of 5000 square feet (hereinafter $5 \mathrm{k}$ ) in its U1 zone. That figure also remains unaltered. ${ }^{35}$ When Euclid first adopted zoning in 1922, over half of the village was undeveloped. Euclid's initial zoning map, foreshadowing the usual devotion of local officials to detached houses, placed $52 \%$ of the suburb's total land area in the U1 zone. The neighborhoods so designated lay primarily either in the Village's northern area bordering Lake Erie, or south of Euclid Boulevard, the thoroughfare that the plaintiff Ambler Realty Company's tract abutted.

Since 1922, Euclid has reduced the acreage that it zones U1 by about one-fourth. But the city has made these reductions almost exclusively in neighborhoods where streets had not been installed in 1922. In 1922, Euclid lots comprising a total of 1282 acres satisfied all of the following three criteria: they (1) were zoned U1; (2) lay in a neighborhood where Euclid's 1922 zoning map indicates that developers had already mapped or installed streets; and (3) did not abut either Euclid Avenue or Lake Shore Boulevard, the city's two principal arterial streets. In 2017, of the acreage that satisfied these three criteria in 1922, Euclid continued to zone $99.0 \%$ single-family (U1). See Table $1 .{ }^{36}$ By contrast, in neighborhoods where internal streets had not been laid out in 1922, single-family zoning was not nearly as sticky. In them, Euclid has rezoned $24.3 \%$ of the land area away from U1. And Euclid has virtually abandoned single-family zoning along its two major arteries, paring the U1 acreage along them from $82 \%$ in 1922 to $7 \%$ in 2017 . See Table 2.

33. See Zoning Map: Euclid Village, Codes Project, http://codesproject.asu.edu/sites /default/files/1922\%20Zoning\%20Map_0.jpg [https://perma.cc/L74C-8LBT].

34. City of Euclid, Ohio, Code of OrdinanCes $§ 1351.022$ (2020).

35. Id. $\S 1381.01$. This provision establishes $5 \mathrm{k}$ as the usual minimum lot size in an A-1 area zone. Euclid's 1922 zoning map states that all U1 zones are in A-1 area districts.

Euclid has made a major change in its zoning policy during the past century, an amendment with an exclusionary thrust. The Village's 1922 map placed roughly one-third of village acreage in commercial and industrial zones. The Village's zones then were cumulative, permitting owners of land in those zones to erect residential structures, including apartment buildings. Euclid's present zoning ordinance is noncumulative. Id. $\S \S 1339.01-.06$. For criticism of the demise of the cumulative approach, see Roderick M. Hills, Jr. \& David Schleicher, The Steep Costs of Using Noncumulative Zoning to Preserve Land for Urban Manufacturing, 77 U. CHI. L. REv. 249, 251-56 (2010).

36. Two-thirds of the $1.0 \%$ - the area rezoned away from U1-Euclid placed in a Campus-Institutional zone to enable the opening of the Forest Park Middle School on Elinore Avenue. 
Table 1: Stickiness, Over Time, of Euclid's 1922 U1 Zones

(Single-Family Detached)

\begin{tabular}{l|c|c} 
& $\begin{array}{c}\text { Still zoned U1 } \\
\text { in 2017 }\end{array}$ & $\begin{array}{c}\text { Greater residential density } \\
\text { permitted in 2017 }\end{array}$ \\
\hline $\begin{array}{l}\text { Neighborhoods where streets had been } \\
\text { laid out in 1922 }\end{array}$ & $99.0 \%$ & $0.3 \%$ \\
\hline $\begin{array}{l}\text { Neighborhoods where streets had } \text { not } \\
\text { been laid out in 1922 }\end{array}$ & $75.7 \%$ & $9.1 \%$
\end{tabular}

Table 2: Euclid's Zoning Along Its Two Major Arteries, Euclid Ave. and Lake Shore Blvd.

\begin{tabular}{l|c|c} 
& 1922 Zoning Map & 2017 Zoning Map \\
\hline \% zoned single-family (U1) & $81.7 \%$ & $6.8 \%$ \\
\hline \% permitting multifamily use & $9.7 \%$ & $16.3 \%$
\end{tabular}

Euclid's zoning history supports several inferences. Once minor interior streets have been laid out within a neighborhood, it strongly affirms this Article's central thesis that single-family zoning then is encased in a political straitjacket. In some contexts, however, Judge Westenhaver's straitjacket metaphor exaggerates the stickiness of zoning. Prior to the layout of local streets, a single-family zone is somewhat easier to override. Moreover, when lots front on a major thoroughfare, zoning politics seems to be more fluid.

\section{The Levittowns}

To broaden the geographic diversity of the localities examined, I added the three largest Levittowns without knowing what the results would bring. During the postwar period, Levitt \& Sons, the developer of these communities, was a successful high-volume homebuilding firm. ${ }^{37}$ In the late 1940 s, the company started the first of the Levittowns in the Town of Hempstead, Nassau County, New York. This Levittown eventually comprised over 17,000 detached houses, similar in design, on lots of roughly 6000 square feet. ${ }^{38}$ Many purchasers promptly remodeled their houses to differentiate them. ${ }^{39}$ But Levittowners, despite their itch to remodel, were also

37. See Levitt \& Sons, WIKIPEDIA, https://en.wikipedia.org/wiki/Levitt_\%26_Sons [https://perma.cc/L9EB-BUGH].

38. See James F. Peltz, It Started with Levittown in 1947: Nation's First Planned Community Transformed Suburbia, L.A. TIMES (June 21, 1988), https://www.latimes.com /archives/la-xpm-1988-06-21-fi-4744-story.html [https://perma.cc/7TJ6-DC75]. Google Earth was used to estimate average lot size in Levittown, N.Y.

39. See Julie Lasky, Levittown, N.Y.: The Original Starter Community, N.Y. Times (Dec. 19, 2018), https://www.nytimes.com/2018/12/19/realestate/levittown-ny-the-original-starter -community.html [https://perma.cc/8PFC-S7V2]. 
committed to suppressing deviations from single-family use. In 1975, when some of the covenants assuring single-family use in this six-square-mile territory were about to expire, Levittown, New York, residents successfully lobbied the Town of Hempstead to freeze permanently the single-family character of all Levitt subdivisions. ${ }^{40}$ Score one for the straitjacket thesis.

Mostly during the 1960s, Levitt \& Sons developed Willingboro, New Jersey, the last of the company's three most massive developments. Willingboro Township's current zoning map also places all Levittown neighborhoods of detached houses in zones that permit no other use. ${ }^{41}$ Score two for the thesis.

Evidence from Levittown, Pennsylvania, is more mixed. Falls, Middletown, and Bristol Townships largely control the local zoning. ${ }^{42}$ Consistent with the straitjacket thesis, the Falls and Middletown Township ordinances restrict future uses in all Levitt subdivisions to single-family detached houses. ${ }^{43}$ But Bristol Township, which encompasses about half of Levittown, Pennsylvania, has placed about three-quarters of its Levittown subdivisions in an R-3 zone that permits, in addition, "multiplefamily dwellings." ${ }^{44}$ But few, possibly none, have actually been built in that zone. ${ }^{45}$ Of the three Levittowns, the total score supporting the straitjacket thesis thus is at least two and one-half.

\section{B. Straitjacketed Single-Family Neighborhoods in Three Metropolitan Areas}

As mentioned, to compare policies in different parts of the country, I intensively researched zoning practices in three metros: Silicon Valley; Greater New Haven, Connecticut; and the northwestern sector of Greater Austin, Texas.

40. Town of Hempstead, N.Y., BuIlding Zone Ordinance, art. XV $\S$ 177, 193 (2019). The "Levittown Planned Residence District" restricts uses to "single-family detached or senior residence," and imposes a minimum lot size of $6 \mathrm{k}$, thereby preventing the subdivision of most existing lots. $I d$.

41. Burlington County, N.J., provides the best available zoning map of Willingboro. Map 4m-38: Willingboro Township Zoning, BuRLINGTON COUNTY, N.J., http://www.co.burlington .nj.us/DocumentCenter/View/6714/Map4M-38?bid [https://perma.cc/BW65-KX6Y].

42. See "Map of the municipalities, school districts and original sections of Levittown" (illustration), on WIKIMEDIA (Feb. 20, 2006), https://en.wikipedia.org/wiki/Levittown, _Pennsylvania\#/media/File:Levittown8.jpg [https://perma.cc/J4H2-SKW5].

43. See Township of FAlls, PA., Code of Ordinances $\S 209-20$ (2019) (adopting a special "Neighborhood Conservation Residential District" to assure this outcome); Middletown Township, Pa., Zoning Map (May 2018), https://www.middletownbucks.org /Community/Township-Info/Maps/march-202018-20zoning-20map-20pdf-1

[https://perma.cc/7PFC-XKSA] (indicating that all Levitt subdivisions had been placed in single-family zones).

44. Bristol Township, PA., COde of Ordinances $\S$ 205-28(A)(2) (2019). The Township's zoning map, dated Dec. 31, 2014, is available at http://www.bristoltownship.org /Bristol\%20Township\%20Zoning\%20Map.pdf [https://perma.cc/WZH7-FBBT].

45. Forays on Google Earth and Trulia-For-Rent turned up no multifamily structures in areas that clearly had originally been Levitt \& Sons subdivisions. On August 1, 2018, the author sent an inquiry about actual land uses to the head of Bristol Township's Building, Planning, and Zoning department, who declined to answer it. 


\section{Silicon Valley}

In this region of sky-high housing prices, market pressures to bring townhouses and apartments to single-family neighborhoods have been especially intense. Zoning authorities nonetheless seldom bend to these forces. Moira O'Neill, Giulia GualcoNelson, and Eric Biber's valuable empirical study of Bay Area zoning practices included interviews with insiders. The various experts identified the existence of a "grand bargain" on housing issues: zoning officials, as long as they would "leav[e] the low-density residential neighborhoods alone," could approve the densification of other venues. ${ }^{46}$ During 2014-2016, the City of San Francisco approved ninety-four projects containing five or more housing units. Reflecting the robustness of the grand bargain, only two of these ninety-four projects replaced prior residential uses. ${ }^{47}$

The center of Silicon Valley lies thirty miles southeast of San Francisco. Sixteen municipalities zone most of this area. All sixteen consistently resist residential densification of existing single-family neighborhoods. Apartment developers have had success primarily in either formerly industrial areas, such as North San Jose, or already densely built-up areas, such as downtown Redwood City. ${ }^{48}$

Closer looks at the zoning histories of two Silicon Valley suburbs-Palo Alto and the much less wealthy East Palo Alto-strongly support the straitjacket thesis. Palo Alto, the epicenter of Silicon Valley, has many existing single-family neighborhoods, and the city's politics tends to freeze land uses in all of them. Indeed, "protect the neighborhoods" has long been the explicit credo of the Residentialists, a major force in Palo Alto politics since the 1960s. ${ }^{49}$ Three of Palo Alto's oldest neighborhoods of houses - Crescent Park, Old Palo Alto, and Professorville- - lie in the northern part of the city. In 1922, Palo Alto's initial zoning map placed virtually all of these three neighborhoods, even lots abutting collector streets, in single-family zones. There, with exceptions amounting to less than $1 \%$ of their combined area, they remain a century later. ${ }^{50}$

Beginning in 1925, Palo Alto annexed large areas to the south. During the 1950s and 1960s, homebuilders such as the innovative Joseph Eichler converted much of south Palo Alto from orchards into tract houses. In those decades, the city placed most of south Palo Alto in an R-1 zone. That designation restricted land uses to a detached house on a lot of at least 6000 square feet, the area of a typical Levittown, New York, lot. In 2020, these tract houses, more affordable than those in Palo Alto's

46. Moira O'Neill, Giulia Gualco-Nelson \& Eric Biber, Developing Policy from the Ground Up: Examining Entitlement in the Bay Area to Inform California's Housing Policy Debates, 25 HASTINGs EnV'T L.J. 1, 68 (2019).

47. Id. at 64 . The authors do not disclose whether the prior residential uses had been single-family or multifamily.

48. Ellickson, supra note 8, at 46-47.

49. Ward Winslow, Palo Alto: A Centennial History 57 (Gain A. John \& Louis C. Brenner eds., 1993).

50. Crescent Park was the site of the most notable rezoning away from single-family. No later than 1955, Palo Alto, then a pro-growth city, rezoned 2\% of the area of Crescent Park from single-family to multifamily use. The sites of these rezonings were the three block-faces along University Avenue just north of downtown Palo Alto. 
fancier northern neighborhoods, were selling for about $\$ 2$ million each. ${ }^{51}$ Six decades after the original development of its southern single-family areas, Palo Alto continues to place more than $99 \%$ of these neighborhoods in an R-1 zone. ${ }^{52}$

California law requires that a city's zoning policies be consistent with its general plan. ${ }^{53}$ The general plan that Palo Alto adopted in 2017 indicates the city's intention to continue to bar multifamily buildings in all of its existing single-family neighborhoods. ${ }^{54}$ In 2014-2016, Palo Alto approved five projects containing five or more dwelling units. None replaced single-family detached houses. ${ }^{55}$

Events in 2013 demonstrate the depth of Palo Alto's antagonism to dense housing at the fringe of a single-family neighborhood. The nonprofit Palo Alto Housing Corporation had proposed the four-story, sixty-two-unit Maybell project, a partially subsidized multifamily development designed primarily for seniors. The city had long zoned the site at issue for multifamily use. Existing houses bordered only one side of the site. The architectural plans called for construction of some two-story, single-family houses to buffer those houses from the taller building. The Palo Alto City Council voted unanimously to approve the Maybell project. The city's approval enraged homeowners in nearby single-family neighborhoods. Citing concerns about traffic and increased density, opponents organized Palo Altans to Preserve Neighborhood Zoning. The group gathered thousands of signatures, enough to place the issue on the ballot. In November 2013, 56\% of Palo Altans voted to scotch the Maybell development. ${ }^{56}$

In recent decades, Palo Alto in fact has approved a dozen or more proposals for multifamily development. But local politics has required that virtually all of these

51. Homes for Sale \& Real Estate in 94306, TRULIA, https://www.trulia.com/CA /Palo_Alto/94306/ [https://perma.cc/AFA8-QZJJ] (searched Oct. 26, 2020).

52. One of Palo Alto's recent changes in zoning policy reduces the potential population of south Palo Alto. At the behest of homeowners devoted to preserving Eichler designs and protecting the privacy of their backyards, the city has entitled homeowners in a single-family neighborhood to vote to recommend limiting the heights of houses to a single story. See CiTY of Palo Alto, Cal., Municipal Code $§ 18.12 .100$ (2019). Between 1992 and 2018, Palo Alto approved single-story overlays of this sort in a dozen small areas, mostly Eichler subdivisions in south Palo Alto. For the locations affected, see the map at "Single-Story Overlay Districts in Palo Alto," SCRIBBLE MAPS, https://www.scribblemaps.com/maps/view/Single-story overlay_districts_in_Palo_Alto/5w49nv_ojm [https://perma.cc/Z2RF-XKNL].

53. CAL. GOV'T CODE $\S 65860$ (West 2009).

54. See City of Palo Alto, Cal., Comprehensive Plan 2030 (2017), https://www.cityofpaloalto.org/gov/depts/pln/long_range_planning/2030_comprehensive plan/default.asp [https://perma.cc/UTP2-Z5Y7]. Map L-6, which follows p. 28, designates all current neighborhoods of detached houses as "single family res," a category that precludes multifamily housing, although not necessarily duplexes or accessory dwelling units. See id. at 31.

55. O'Neill et al., supra note 46, at 64. My thanks to Moira O'Neill, Giulia GualcoNelson, and Eric Biber for providing project addresses, which enabled me to determine prior land uses.

56. Jason Green, Voters Reject Affordable Senior Housing Project in Palo Alto, MERCURY News (Nov. 5, 2013, 2:25 PM), https://www.mercurynews.com/2013/11/05/voters-reject -affordable-senior-housing-project-in-palo-alto/ [https://perma.cc/7B76-5G4E]. 
projects be sited one or more blocks away from NIMBYish homeowners. ${ }^{57}$ The approved projects have typically been sited either in Palo Alto's downtown or in zones where the city has long authorized either multifamily, planned-community, or, most commonly, industrial use. ${ }^{58}$

The zoning politics of East Palo Alto, Silicon Valley's least-prosperous suburb, is equally respectful of existing single-family neighborhoods. Incorporated in 1983, East Palo Alto is Silicon Valley's newest city, and also its only municipality whose territory lies mostly east of the Bayshore Freeway (U.S. 101). In the early 1950s, residents of the area that later became East Palo Alto were almost entirely White. The area had turned majority Black by the mid-1960s, and, after 2000, majority Hispanic. ${ }^{59}$ East Palo Alto's most recent zoning map places $79 \%$ of its residentially zoned territory in a zone that permits only single-family detached houses on lots of at least 5000 square feet. ${ }^{60}$ Land uses in these neighborhoods are as frozen as they are in Palo Alto. East Palo Alto's general plan explicitly declares the goal of "preserv[ing] the character of existing single-family neighborhoods." ${ }^{\circ}$ One such neighborhood is University Village, which lies in the far north of the city. A few blocks to the west, Facebook is planning a 1500-housing-unit development in the City of Menlo Park. ${ }^{62}$ Yet East Palo Alto's specific plan for the University Village area explicitly pledges to protect that neighborhood's single-family character. ${ }^{63}$

\section{Greater New Haven}

In this metro, where the fourteen suburbs generally are more exclusionary than those in either Silicon Valley or northwestern Greater Austin, single-family

57. Stanford University erected houses, for example, to buffer its new mid-rise University Terrace condominiums from pre-existing single-family homes in College Terrace. See https://universityterrace.stanford.edu/community/interactive-map [https://perma.cc/335Z4MFD].

58. Multifamily projects in former Palo Alto industrial zones include those on Berryessa Street, Fabian Way (the Taube Koret development), and Feather Lane.

59. Kim-Mai Cutler, East of Palo Alto's Eden: Race and the Formation of Silicon Valley, TECH CRUNCH (Jan. 10, 2015, 5:08 PM), https://techcrunch.com/2015/01/10/east-of-palo-altos -eden/ [https://perma.cc/P46R-RE9V]; East Palo Alto, California, WiKIPEDIA (Sept. 23, 2020, 1:16 PM), https://en.wikipedia.org/wiki/East_Palo_Alto,_California [https://perma.cc/PMQ2 -APEZ].

60. City of East Palo Alto, Cal., Code of Ordinances, $\S 18.10 .030$ tbl.2.2 (2020).

61. City of East Palo Alto, Cal., Vista 2035: East Palo Alto General Plan, Goal LU-5, at 4-22 (Mar. 2017).

62. Kurt Wagner, Facebook Is Building a New Campus that Includes 1,500 Apartments and a Grocery Store, Vox (July 7, 2017, 12:21 PM), https://www.recode.net/2017/7/7 /15935032/facebook-mark-zuckerberg-new-campus-expansion-willow-menlo-park [https://perma.cc/PUK5-KHLN].

63. East Palo Alto, Cal., Ravenswood/Four Corners TOD Specific Plan 48 (Feb. 22, 2013) (" $[\mathrm{N}] \mathrm{o}$ land use changes are proposed in the University Village neighborhood . . .”). Some observers hope that NIMBYists would be less able to influence a locality's general plan than its zoning ordinance. Roderick M. Hills, Jr. \& David Schleicher, Planning an Affordable City, 101 IowA L. REV. 91 (2015). This nugget of evidence from East Palo Alto suggests otherwise. 
neighborhoods are as ubiquitous and frozen as those we have examined thus far, if not more so. In 1958, Bethany, Connecticut, adopted an ordinance that barred all forms of new residential construction other than a detached house. ${ }^{64}$ Of the thirtyseven suburbs studied, Bethany's was the purest expression of devotion to life in separate dwellings. In 2015, New Haven's five most exclusionary suburbs, a group that includes Bethany, insisted on detached houses on $99.5 \%$ of their residentially zoned territory. Their few zones that allow duplexes and multifamily housing tend to lie near these towns' commercial areas, where homeowners seem to regard those uses to be less threatening.

New Haven's three working-class suburbs-East Haven, West Haven, and Meriden - have been far more tolerant of diverse forms of residential living. They permit duplexes, or even denser residential uses, on $26 \%$ of their residentially zoned territory, a percentage fifty times greater than what New Haven's most exclusionary suburbs permit $(0.5 \%)$. Nonetheless, even these three less tony suburbs set aside $74 \%$ of their residentially zoned land exclusively for detached houses. Their single-family zones appear in large, sometimes concentrated, swaths on their zoning maps. West Haven, for instance, permits only detached houses in the southwestern $40 \%$ of the city (excluding the beachfront). East Haven similarly bars duplexes and apartments in its northern $20 \%$. Of these three working-class suburbs, Meriden has been the most flexible. It has frequently approved developers' applications for the equivalent of a Planned Unit Development (PUD), at times including multifamily housing, on a largish tract of undeveloped land. ${ }^{65}$ The ultimate form of residential densification would be the replacement of existing detached houses, in an area formerly zoned single-family, with townhouses or apartments. In New Haven's blue-collar towns, as elsewhere, this seldom occurs.

\section{Greater Austin}

Texas generally is a pro-growth state. The disproportionate size of the state's housing industry, and the self-sorting of immigrants by ideology, may both have contributed to this inclination. ${ }^{66}$ A look at the zoning histories of four of the oldest localities in the northwest sector of Austin, however, suggests that zoning politics in Texas hardly prevents homeowners from straitjacketing an established single-family neighborhood.

The City of Austin, incorporated in 1839, is the oldest city in Greater Austin. Austin's politicians recently discovered the political clout of homeowners opposed to densification. A century ago, when Texas's capital city was lightly populated, subdividers created, within a mile or two of Austin's downtown core, a number of low-density, largely residential neighborhoods. Among them were Bouldin Creek, Clarksville, and East Austin. Many lot owners in these neighborhoods built singlefamily detached houses, a use adapted to the market conditions then prevailing.

64. Town of Bethany, Conn., Zoning Ordinance, revision of June 19, 1958, at 10.

65. See City of Meriden, Conn., Zoning Map (Dec. 12, 2019 revision). The PUD approach entitles a developer who owns a largish tract to propose a mix of land uses, including perhaps multifamily housing and commercial structures. The municipality, of course, must agree to the proposal.

66. See infra text accompanying notes $138-50$. 
Today, the City of Austin's population approaches one million, and its downtown is insufficiently large and dense for a city of its size. Mayor Steve Adler, first elected in 2015, recognized this obsolescence. In the late 2010s, he helped sponsor CodeNEXT, a measure designed to increase permitted residential densities in closein locations. ${ }^{67}$ This proposal stirred opposition in the older Austin neighborhoods near downtown, including the three just mentioned. CodeNEXT's supporters eventually were forced to water down the proposal, for example, by exempting some neighborhoods from it. ${ }^{68}$ In August 2018, Mayor Adler bowed to the political power of the NIMBY opposition and pulled the plug on CodeNEXT, at least temporarily. ${ }^{69}$

The history of Tarrytown, an upscale Austin neighborhood a bit west of downtown, also illustrates the constraints of Texas zoning politics. ${ }^{70}$ Excluding Tarrytown's fringes, Austin's zoning rules limit residential uses in $97 \%$ of the neighborhood to single-family detached houses. ${ }^{71}$ Perhaps because of the pro-growth inclinations of Texas culture, a few developers have succeeded in recent decades in winning Austin's approval of PUDs that have brought denser residential uses to Tarrytown. Nonetheless, these PUD developments, taken together, comprise just over $1 \%$ of the neighborhood's land. ${ }^{72}$ Absent state intervention, zoning politics in Austin is likely to freeze single-family uses in Tarrytown nearly as permanently as it would in other metros.

The City of Georgetown, which dates from 1848, is the second oldest of the Greater Austin cities studied. Georgetown's 2020 zoning map includes an "Old Town Overlay," an area of roughly 200 square blocks. ${ }^{73}$ Despite what its name implies, Old Town is hardly a bastion of density. In about $97 \%$ of the area,

67. See Randy Shaw, Generation Priced Out: Who Gets to Live in the New Urban AMERICA 95-102 (2018) (describing CodeNEXT, prior to its demise).

68. See Michael Theis, Austin Urbanist Group Slams Draft CodeNEXT Map for Perceived Lack of Density, Austin Bus. J. (Apr. 20, 2017, 9:09 AM), https://www.bizjournals .com/austin/news/2017/04/20/austin-urbanist-group-slams-draft-codenext-map-for.html [https://perma.cc/CN9P-Q3R5].

69. Leah Binkovitz, What's Next for CodeNEXT? Planning, Nov. 2018, at 12-13. In 2012, the City of Austin shifted from electing city council members at large to electing them in separate districts. This structural change, motivated in part to enhance the racial diversity of the council, may have strengthened the forces of NIMBYism and helped doom CodeNEXT, at least temporarily. See also infra text accompanying notes 103-05.

70. Tarrytown is defined here as the area south of West 35th Street, west of MoPac, north of Enfield Road, and east of Lake Austin.

71. Austin's predominant zone in Tarrytown, SF-3-NP, nominally also permits duplexes. The suffix -NP signals, however, that a neighborhood plan would bar those uses. The Central West Austin Neighborhood Plan does so, proclaiming an intention to "[p]reserve and protect the historic character and integrity of Central West Austin's predominantly single-family neighborhoods." The Central West Austin Neighborhood Plan, An Amendment to the Austin Tomorrow Plan, AustinTeXAs.Gov 38 (2010), http://www.austintexas.gov/page/adopted -neighborhood-planning-areas-0 [https://perma.cc/ZQ9H-3R68].

72. For their locations, see Zoning Totals, AUSTIN MAPS, http://austin.maps.arcgis.com /apps/webappviewer/index.html?id=9568ee27c9564150939fd720bf100dce [https://perma.cc /EMG9-ESWE].

73. Georgetown, TeX., Official Zoning Map, Sept. 22, 2020, https://georgetown.org /gis/pdfs/ZoningMap_Esize.pdf [https://perma.cc/LP85-8HNQ]. 
Georgetown's zoning permits, as a residential use, only a detached house. No more than two blocks (roughly 1\%) of Old Town is zoned for multifamily housing. These blocks are the sites of the area's largest apartment complexes, one- or two-story structures built in the 1960 s. ${ }^{74}$ Since the 1960 s, with rare exception, Georgetown's zoning politics has protected Old Town house owners from not only townhouses and apartments, but also duplexes.

Two of Austin's wealthiest suburbs, Rollingwood and West Lake Hills, are relatively old for the region. Located a few miles west of downtown Austin, developers created these two small cities in the 1950s ${ }^{75}$ Their founders, however, plainly foresaw them almost exclusively as havens for life in detached houses. The housing stocks of the two suburbs contain little else. West Lake Hills requires a minimum house lot of one acre on $98.8 \%$ of its residentially zoned land, and Rollingwood requires a minimum of $15 \mathrm{k}\left(15,000 \mathrm{sq}\right.$. ft.) on $100 \%{ }^{76}$ These minimum requirements are significantly smaller than those in, say, Bethany, Connecticut, but the devotion of these elite Austin suburbs to detached-house living is virtually as fervent. ${ }^{77}$ Local political forces in both West Lake Hills and Rollingwood would almost certainly doom rezonings to permit greater residential density. The zoning straitjacket plainly extends to Texas.

\section{Exceptions to the Straitjacket: Neighborhoods near a New Transit Node}

Nonetheless, there is some play in the joints. In exceptional cases, local politics does permit a suburb to densify an existing single-family neighborhood. Urban researchers should more thoroughly investigate when and where this is possible. ${ }^{78}$ Here are some preliminary thoughts.

Changes in transportation networks appear to be the events most likely to loosen the straitjacket. When a nearby transit hub or corridor has just opened, or is scheduled to open, the prospect of profit may tempt some nearby homeowners to support densification. One of the best-documented cases is the opening, in 1977, of the D.C. Metro's Courthouse station in Arlington, Virginia. In that instance, the new station

74. These are Alpine Apartments, 806 E. 13th St., and Mid-Century Park, 900 E. 13th St.

75. West Lake Hills, largely developed by Emmett Shelton Sr., was incorporated as a city in 1953. Rollingwood, a creation of George B. Hatley, became a village in 1955. The planning department of neither city was able to provide a copy of its earliest zoning map.

76. West Lake Hills's zones permit two-family structures on $0.9 \%$ of its residentially zoned land, and multifamily uses on $0.3 \%$. The two principal existing multifamily structures are located in extreme corners of the city.

77. Cf. supra text accompanying note 64. The Travis County Central Appraisal District maintains a database of actual parcel sizes. See Travis CAD Map Search, HARRIS Govern, http://propaccess.traviscad.org/mapSearch/?cid=1 [https://perma.cc/334T-U8K6]. A researcher could use the database to examine the influence of zoning on lot sizes.

78. For Issi Romem's assessment, see Romem, supra note 30. Valuable studies of patterns of rezonings include Vicki Been, Josiah Madar \& Simon McDonnell, Urban Land-Use Regulation: Are Homevoters Overtaking the Growth Machine?, 11 J. EMPIRICAL LEGAL STUD. 227 (2014) (focusing on New York City); John Mangin, Ethnic Enclaves and the Zoning Game, 36 Yale L. \& Pol'y Rev. 419 (2018) (same); and Eric H. Steele, Participation and Rules-The Functions of Zoning, 1986 AM. BAR FOUND. RsCH. J. 709, 731 (studying zoning changes in Evanston, Illinois, a dense suburb north of Chicago). 
prompted nearly two dozen nearby homeowners to assemble their lots for eventual sale to a developer, and to support the rezoning of their neighborhood for highdensity residential use. ${ }^{79}$ These moves enabled them to reap roughly three times the pre-station market value of their houses. ${ }^{80}$ In New York City, between 1920 and 1960, apartment buildings similarly replaced single-family houses in some neighborhoods near subway lines. ${ }^{81}$ State Senator Scott Wiener of California, recognizing the complementarity of transit and dense housing, has introduced a much-discussed bill to compel local governments to allow greater residential densities near both new and existing transit nodes. ${ }^{82}$

Some cities in all three metros have adopted Transit Oriented Development (TOD) zoning policies that deliberately raise permitted residential densities near rail or express-bus stations. ${ }^{83}$ When a new station on the Metro-North line opened in West Haven in 2013, the city placed the surrounding area in a TOD zone. In this zone, West Haven permits the construction of apartment buildings as tall as eight stories. ${ }^{84}$ Austin's TOD district authorizes residential buildings as tall as sixty feet near the East Austin mass transit station. ${ }^{85}$ Palo Alto is more averse to bulk. Its sole TOD district is near the less central California Street station, not the downtown Caltrain station. At California Street, Palo Alto's TOD policy limits building heights to forty feet. ${ }^{86}$

Densification near a new mass transit station is far from inevitable. A familiar joke among transportation planners is that every commuter rail line eventually is correctly located because land uses invariably densify near stations. ${ }^{87}$ Not so. ${ }^{88}$

79. Thomas A. Clary \& Paul W. Rasmussen, The Buyout Phenomenon, Planning, Oct. 1985, at 18; see also William E. Schmidt, Owners Uniting to Sell Homes to Developers, N.Y. TIMES (Jan. 16, 1985), https://www.nytimes.com/1985/01/16/us/owners-uniting-to-sell -homes-to-developers.html [https://perma.cc/5AMK-RR69] (describing assemblage and sale, for an office complex, of 144 houses north of Atlanta near the MARTA Dunwoody station).

80. Clary \& Rasmussen, supra note 79, at 20.

81. See Robert A.M. Stern, Thomas Mellins \& David Fishman, New York 1960: Architecture and Urbanism Between the Second World War and the Bicentennial (1995), at 799-830 (Upper East Side of Manhattan), 993-97 (Queens Boulevard).

82. SB-50 (Cal. 2018), https://leginfo.legislature.ca.gov/faces/billTextClient.xhtml?bill _id=201920200SB50 [https://perma.cc/58LM-8DHR].

83. See, e.g., Arefeh Nasri \& Lei Zhang, The Analysis of Transit-Oriented Development (TOD) in Washington, D.C. and Baltimore Metropolitan Areas, 32 TRANSPORT POL'y 172 (2014); Arthur C. Nelson, Transit-Oriented Developments Make a Difference in Job Location, 44 FordHAM URB. L.J. 1079 (2017).

84. City of West Haven, Conn., Zoning Regulations p. 35-20 tbl.35.1.7 (2019). By 2019, no TOD projects had actually commenced. Interview with David Killeen, Assistant Planner, City of West Haven, Conn. (Aug. 21, 2019).

85. City of Austin Neighborhood Plan. \& Zoning Dep't, Martin Luther King (MLK) BLVD. TOD StATION AREA Plan, at 8, 39, http://www.austintexas.gov/sites/default /files/files/Planning/Urban_Design/MLK_Jr._Blvd._Final_SAP_Low_Res.pdf [https://perma.cc/JAA7-8DBJ].

86. Palo Alto, Cal, Code of Ordinances, § 18.34.040 tbl.2 (2019).

87. Bert van Wee, Viewpoint: Toward a New Generation of Land Use Transport Interaction Models, 8 J. TRANSPORT \& LAND Use 1, 1 (2015).

88. See David Schleicher, How Land Use Law Impedes Transportation Innovation, in 
Atherton, California, permits only single-family uses near its station on the Caltrain commuter line. Three-quarters of the land within one-half mile of the Tacoma Park, Maryland, Metro station is zoned solely for detached houses. ${ }^{89}$ Many of New York City's recent rezonings have lowered residential densities near mass transit stations. $^{90}$

Proximity to a major highway at times also can change the dynamics of zoning politics. Homeowners near exits from interstate highways may support rezonings for dense residential and commercial use. ${ }^{91}$ Frontage on a major arterial street also can help loosen zoning restrictions. As noted, in 1922, Euclid zoned 82\% of the area fronting on Euclid Avenue and Lake Shore Boulevard, two of its major thoroughfares, only for single-family use. By 2017, Euclid had reduced the singlefamily percentage along these arteries to $7 \%$ and was zoning $16 \%$ of the frontage for multifamily housing. ${ }^{92}$ Frontage on a mere collector street, a roadway less wide than an arterial, occasionally may also be sufficient. In the 1950s, Palo Alto, then in a progrowth mode, rezoned several blocks along University Avenue just northeast of downtown to permit multifamily development. ${ }^{93}$

Exceptions to the straitjacket, other than proximity to a transit node, may exist. ${ }^{94}$ However, none seems as plain. Some observers have assumed that homeowners in a neighborhood that is both relatively poor and relatively nonwhite would lack political power, and therefore be more vulnerable to densification. ${ }^{95}$ The zoning history of the East Austin neighborhood may support this conjecture. ${ }^{96}$ In 2014, however, three of

Evidence and Innovation in Housing Law And Policy 38, 44-45 (Lee Anne Fennell \& Benjamin J. Keys eds., 2017) (doubting that zoning officials permit sufficient densification near transit stations).

89. Tracy Hadden Loh, How Well Is the Region Doing at Planning for Growth Near Metro?, Greater GREATER WASHINGTON (Jan. 30, 2019), https://ggwash.org/view/70464 /transit-oriented-delopment-are-we-upzoning-near-metro-rail-washington-region [https://perma.cc/8272-SYPV].

90. Hills \& Schleicher, supra note 19 , at 85.

91. See Ruth Knack \& James Peters, Starting to Spread, Planning, Oct. 1985, at 21, 22 (mapping examples along Interstate 285 north of Atlanta); see also Donald Shoup, Graduated Density Zoning, 28 J. PlanNING EDUC. \& Rsch. 161, 172-74 (2008) (describing the willingness of Simi Valley, California, to reduce its required minimum house lot size from $20 \mathrm{k}$ to $2.85 \mathrm{k}$ at a site several hundred yards from a freeway exit).

92. See supra Table 2, following n.36.

93. See supra note 50.

94. Two low-probability scenarios warrant brief mention. A neighborhood disaster, natural or man-made, may nudge local politicians to favor densification. See Richard Hornbeck \& Daniel Keniston, Creative Destruction: Barriers to Urban Growth and the Great Boston Fire of 1872, 107 AM. Econ. REV. 1365 (2017); Gerard H. Dericks \& Hans R.A. Koster, The Billion Pound Drop: The Blitz and Agglomeration Economics in London (CEP Discussion Paper No. 1542, April 2018). Pro-density religious preferences also may alter zoning politics. A group of Hasidic Jews supported the conversion of a Brooklyn neighborhood from single-family dwellings to multi-story walkup apartments. Mangin, supra note 78 , at $441-42$.

95. See Romem, supra note 30.

96. See Wilhelmina Delco, I've Lived in East Austin for 60 Years, and I Don't Recognize It Anymore, TEXAS OBSERver (Nov. 20, 2019 3:16 PM), https://www.texasobserver.org/ive 
the many suburbs discussed above were both lower income and majority minority: East Palo Alto, Euclid, and Willingboro. ${ }^{97}$ In the 2010s, all three were staunchly committed to keeping densifiers away from their single-family neighborhoods. ${ }^{98}$

The straitjacket might also tend to be looser in a locality with a large population, where politics likely is more pluralistic than in a lightly populated suburb where homeowners predominate. ${ }^{99}$ Minneapolis has garnered headlines by authorizing the construction of triplexes in zones where it formerly had restricted residential uses to detached houses. ${ }^{100}$ Some recent studies, however, emphasize the strength of NIMBYist homeowners in central cities such as New York City and San Francisco. ${ }^{101}$ And San Mateo and Santa Clara Counties, both populous localities, impose the Silicon Valley's toughest land use controls on Stanford University lands in the Foothills. ${ }^{102}$

How a city structures its local elections may affect the tightness of its straitjacket. Some observers have understandably anticipated that local elected officials would be more responsive to NIMBYist lobbying if elected by district, as opposed to atlarge. ${ }^{103}$ Michael Hankinson and Asya Magazinnik have confirmed this tendency in California, and Evan Mast has confirmed it nationwide. ${ }^{104}$ The importance of the

-lived-in-east-austin-for-60-years-and-i-dont-recognize-it-anymore/ [https://perma.cc/T2AZ $-3 \mathrm{DNW}]$.

97. In 2014, median household income in Euclid was the lowest of all the municipalities studied. Euclid's median was 70\% of the state of Ohio's and 25\% of Palo Alto's. In 2014, Euclid's population was $59 \%$ African American.

98. See supra text accompanying notes 33-36, 41, 59-63.

99. See Robert C. Ellickson, Suburban Growth Controls: An Economic and Legal Analysis, 86 YALE L.J. 385, 404-09 (1977); see also J. Eric Oliver, City Size and Civic Involvement in Metropolitan America, 94 AM. PoL. SCI. REV. 361, 370-72 (2000) (finding that an increase in the population of a city or suburb produces a falloff in political participation).

100. See Jake Blumgart, Minneapolis Evicts Single-Family Zoning, Planning, Mar. 2019, at 12, 12. Some assert that Grand Rapids acted earlier. See Jared Brey, A Decade Without Single-Family Residential Zoning in Grand Rapids, NEXT CiтY (Dec. 26, 2018), https://nextcity.org/daily/entry/a-decade-without-single-family-residential-zoning-in-grand -rapids [https://perma.cc/CP5W-3LUU]. In 2019, Oregon enacted a statute requiring cities with a population of at least 25,000 to permit denser housing, such as triplexes and townhouses, in all zones designated as single-family only. See Act of Aug. 8, 2019, ch. 639, sec. 2, 2019 Or. Laws 1, 1 (codified at Or. REv. STAT. § 197.758 (2019)). It is too early to speculate how this statute will play out.

101. See Been et al., supra note 78; O’Neill et al., supra note 46, at 68; David Schleicher, City Unplanning, 122 YALE L.J. 1670, 1699 (2013).

102. See Ellickson, supra note 8, at 40-41.

103. See Hills \& Schleicher, supra note 19, at 111-15; Kenneth A. Stahl, The Artifice of Local Growth Politics: At-Large Elections, Ballot-Box Zoning, and Judicial Review, 94 MARQ. L. REV. 1 (2010).

104. See Michael Hankinson \& Asya Magazinnik, Aggregating Voters and the Electoral Connection: The Effect of District Representation on the Distributive Equity of the Housing Supply 4 (Aug. 21, 2019) (unpublished manuscript), http://chriswarshaw.com/lpe_conference /draft_190820.pdf [https://perma.cc/PF26-T7KL] (finding a 44\% drop in permits for multifamily housing); Evan Mast, Warding Off Development: Local Control, Housing Supply, and NIMBYs (Upjohn Inst., Working Paper No. 20-330, 2020), https://research.upjohn.org /cgi/viewcontent.cgi?article=1349\&context=up_workingpapers [https://perma.cc/Q97W 
local electoral system, however, should not be exaggerated. Palo Alto, a paragon of protection of existing single-family neighborhoods, has long elected its city council at-large. ${ }^{105}$

\section{THE POLITICS OF ZONING}

Both federal and state laws constrain a locality's choices in how to zone. Both levels of government have, in selected cases, forced localities to accept, even in existing neighborhoods where detached houses predominate, religious land uses, group homes, and accessory dwelling units. ${ }^{106}$ But the effects of these preemptive overrides have generally been modest. In most of the United States, local officials are still largely free to determine permissible land uses.

Zoning decisions are political outcomes. They tend to reflect the ideologies of local officials, and the interests of those best able to lobby city hall. This Part aims to enhance the sophistication of theories of zoning politics. ${ }^{107}$ Traditionally, few political scientists have been interested in local government. A survey of articles on elections in leading U.S. political science journals found that roughly $94 \%$ focused on federal elections, $6 \%$ on state elections, and less than $1 \%$ on local elections. ${ }^{108}$ Social scientists, however, have increasingly come to recognize the massive effects of local zoning practices on both the national economy and household migration choices. ${ }^{109}$ This has resulted in a boom, or at least a boomlet, of pertinent scholarship.

The first Section of this Part summarizes theories of zoning politics that Harvey Molotch, William Fischel, Roderick Hills, and David Schleicher have advanced. The ensuing sections aspire to develop a theory of zoning politics that makes sense of three of the larger research project's specific findings:

(1) Zoning practices vary significantly by region, with suburbs in Greater Austin generally being far more pro-growth than those in Silicon Valley and Greater New Haven; ${ }^{110}$

(2) Once streets have been laid out in a neighborhood where zoning limits development to detached houses, zoning politics, even in Greater Austin, typically bars any form of denser residential use; ${ }^{111}$ and

$-8 \mathrm{VLS}]$.

105. See Elena Kadvany, District Lawyer: No Evidence of Racially Polarized Voting, PaLO Alto OnLine (Oct. 25, 2018, 9:20 AM), https://paloaltoonline.com/news/2018/10/25/district -lawyer-no-evidence-of-racially-polarized-voting [https://perma.cc/HMN6-DSQJ].

106. See Religious Land Use and Institutionalized Persons Act (RLUIPA), 42 U.S.C. $\S \S$ 2000cc-2000cc-5 (2012); see also Anika Singh Lemar, The Role of States in Liberalizing Land Use Regulations, 97 N.C. L. REv. 293 (2019) (discussing state government intervention in local land use regulation).

107. For a concise overview of existing theories, see Been et al., supra note 78, at 230-38.

108. Christopher R. Berry \& William G. Howell, Accountability and Local Elections: Rethinking Retrospective Voting, 69 J. POL. 844, 845 n.3 (2007).

109. See Ellickson, supra note 8, at 8-9; David Schleicher, Stuck! The Law and Economics of Residential Stagnation, 127 YALE L.J. 78, 102-03 (2017) (summarizing others' findings).

110. See Ellickson, supra note 8, at 12-31.

111. See supra text accompanying notes 29-77. 
(3) The event most likely to loosen this zoning straitjacket is the opening of a new transit node. ${ }^{12}$

The proposed theory is both tentative and eclectic. It assumes that local political actors are influenced by, among other factors, personal political ideologies, neighborhood social pressures, and, most importantly, a psychological disposition that favors maintenance of the status quo.

\section{A. Current Theories of Zoning Politics}

In 1976, Harvey Molotch asserted in an influential article (or at least in the article's title) that a "Growth Machine" dominates local land use politics. ${ }^{113}$ Molotch's central claim was that "elites," who are inherently pro-growth, have an outsized influence on policy. ${ }^{114}$ "Growth Machine," although a memorable phrase, has always mischaracterized certain zoning realities. It ignores policies that are hardly pro-growth - for example, the widespread practice of large-lot zoning. In 1928, Atherton, California, began wielding zoning controls to severely limit density; four years later, Woodbridge, Connecticut, adopted the same strategy. ${ }^{115}$ To his credit, Molotch acknowledged that his title might be claiming too much. He observed that the very rich had been able to create for themselves some "small, exclusive meccas of low density." 116 Living in the Santa Barbara area during the 1970s, Molotch also indicated that he was aware that political tides in California had emphatically shifted away from pro-growth policies. ${ }^{117}$

William Fischel has advanced a theory of local politics that is far more realistic than Molotch's. Fischel coined a neologism, "homevoter," to highlight homeowners' interests in zoning outcomes. ${ }^{118}$ Many homeowners regard their houses among their principal financial assets. Insurance against a decline in house value seldom is available. The effects of local decisions on matters such as zoning and the quality of public schools are largely capitalized into house values. Fischel hypothesizes that homevoters, for him implicitly the political heavyweights in suburbia, tend to favor local decisions that would enhance the value of their abodes. ${ }^{119}$

Recent scholarship generally affirms Fischel's theory that homeowners - not developers - dominate local politics. ${ }^{120}$ Owners of residential dwellings are almost

112. See supra text accompanying notes 78-105.

113. Harvey Molotch, The City as a Growth Machine: Toward a Political Economy of Place, 82 Aм. J. Socio. 309 (1976). But see Been et al., supra note 78 (finding evidence of NIMBYism in New York City, the last place one might expect it).

114. Molotch, supra note 113.

115. See Ellickson, supra note 8, at 23.

116. Molotch, supra note 113, at 327.

117. See id. at 326-29 (mentioning political changes in, among other cities, Palo Alto). On the changing politics of zoning in California, see Ellickson, supra note 8, at 32-33. See also Alan A. Altshuler, Arnold M. Howitt, \& José A. Gómez-Ibáñez, Regulation for REVENUE 19-33 (1993) (discussing causes of the rise of antigrowth sentiment).

118. William A. Fischel, The Homevoter Hypothesis: How Home Values Influence Local Government Taxation, School Finance, And Land-Use Policies ix (2001).

119. Id. at 4 .

120. See Andrew B. Hall \& Jesse Yoder, Does Homeownership Influence Political 
twice as likely as renters to vote in local elections. ${ }^{121}$ In the suburbs of Greater Chicago, Eric Oliver found that homeowners constituted $99.5 \%$ of the candidates for local office. ${ }^{122}$ Homeowners are particularly likely to rouse themselves on zoning issues. ${ }^{123}$ In the Boston region, Einstein, Glick, and Palmer found that homeowners, who constituted a mere $46 \%$ of the general electorate, were $73 \%$ of the commentators at public zoning hearings. ${ }^{124}$ Regardless of ideology, these speakers tended to be skeptical of projects that would densify their neighborhoods. ${ }^{125}$ Einstein and her coauthors also found that residents offering testimony were disproportionately male, white, older, longtime homeowners and were overwhelmingly opposed to new housing construction. ${ }^{126}$ Even renters are potential recruits to NIMBY causes. ${ }^{127}$

Roderick Hills and David Schleicher have offered a theory that nicely supplements Fischel's. ${ }^{128}$ As Fischel well understood, members of two other broadly defined factions have a major stake in zoning outcomes. ${ }^{129}$ One faction consists of housing suppliers - the individuals and firms that would gain financially from housing production. A second faction consists of housing consumers. Consumers benefit when housing suppliers offer more options and housing production is robust enough to dampen increases in rents and sale prices. ${ }^{130}$ Invoking public choice theory, Hills and Schleicher observe that the members of the various local factions

Behavior? Evidence from Administrative Data (Mar. 26, 2019) (unpublished manuscript), https://www.andrewbenjaminhall.com/homeowner.pdf [https://perma.cc/C8TX-GG2L]; see also Andrew H. Whittemore, Zoning Los Angeles: A Brief History of Four Regimes, 27 PLAN. PERSPS. 393 (2012) (describing political trends in a major city).

121. See J. Eric Oliver, Shang E. Ha \& Zachary Callen, Local Elections and the Politics of SMall-Scale Democracy 69 (2012); cf. Hall \& Yoder, supra note 120 (finding that the acquisition of a house increases the likelihood of voting in local elections).

122. OLIVER ET AL., supra note 121, at 99.

123. See id. at 106; Hall \& Yoder, supra note 120.

124. Katherine Levine Einstein, David M. Glick \& Maxwell Palmer, Neighborhood Defenders: Participatory Politics and America's Housing Crisis 101 (2019).

125. See William Marble \& Clayton Nall, Where Interests Trump Ideology: The Persistent Influence of Homeownership in Local Development Politics 2-3 (Jan. 31, 2018) (unpublished manuscript), http://cess.nyu.edu/wp-content/uploads/2018/02/Nall.pdf (finding that selfinterest, not ideology, dominates homeowners' attitudes toward densification).

126. See EINSTEIN ET AL., supra note 124, at 101-14; see also id. at 106 (finding that $62 \%$ of speakers opposed new housing, compared to $15 \%$ in support and $23 \%$ neutral).

127. See Michael Hankinson, When Do Renters Behave Like Homeowners? High Rent, Price Anxiety, and NIMBYism, 112 Am. PoL. SCI. Rev. 473, 482-84 (2018) (finding that renters in high-rent cities are likely to oppose a nearby project that might accelerate gentrification).

128. Hills \& Schleicher, supra note 19.

129. FISCHEL, supra note 118, at 15-16, 257-58.

130. See Vicki Been, Ingrid Gould Ellen \& Katherine O'Regan, Supply Skepticism: Housing Supply and Affordability, 29 Hous. PoL'y DeBATE 25 (2019) (asserting that most evidence indicates that greater housing production dampens housing prices); Stuart S. Rosenthal, Are Private Markets and Filtering a Viable Source of Low-Income Housing? Estimates from a "Repeat Income" Model, 104 AM. ECON. REV. 687 (2014) (discussing how, over time, initially expensive dwellings may become affordable to lower-income families). 
face different collective action problems. ${ }^{131}$ Members of some factions are better able than others to induce lobbying activity, such as attendance at a zoning hearing.

Suppose a public hearing were to be held on a rezoning proposed to densify a portion of Professorville in Palo Alto. ${ }^{132}$ Neighborhood homeowners typically could readily overcome many obstacles to acting collectively. Palo Alto, adhering to a provision in its zoning ordinance, would send, at least ten days in advance of the upcoming hearing, a mailed notice to owners of lots within 600 feet of the land to be rezoned. ${ }^{133}$ Those recipients could readily rally additional opposition by knocking on the doors of neighbors located a bit farther away. Palo Alto's city hall is a ten-minute walk from Professorville. Neighborhood residents could, without cost, confer positive esteem on a homeowner who had stepped forward at the hearing to defend perpetuating the status quo in Professorville. ${ }^{134}$

In this hypothetical situation, housing consumers, by contrast, would face colossal collective action problems. The Palo Alto rezoning would affect the housing options of persons not only throughout the Bay Area, but also, to some extent, worldwide. Consumers' stakes in the outcome of any particular densification proposal are likely to be trivial. And for most affected consumers, the lengthiness of a trip to Palo Alto would deter attendance. ${ }^{135}$

Housing suppliers with a financial stake in a particular Professorville densification project, by contrast, would be intensely motivated to participate. Before the start of construction, however, they likely would be few in number. Some, if resident in another city, also would be unable to vote in a Palo Alto election. Growth machine theorists, of course, might stress that outsiders unable to vote could still make campaign contributions. State and local campaign finance statutes, however, might compel a candidate to disclose political donations. ${ }^{136}$ If so, because developers are highly unpopular, a housing supplier's donation might backfire. ${ }^{137}$

Hills and Schleicher's emphasis on the costs of collective action helps reveal why homevoters have become so powerful in rezoning politics. One upshot has been the zoning straitjacket.

131. See Hills \& Schleicher, supra note 19, at 90-96.

132. See supra text accompanying notes $27-28$.

133. See Palo Alto, Cal., Mun. Code $§ 18.80 .060$ (a)(2) (2020), https://codelibrary .amlegal.com/codes/paloalto/latest/paloalto_ca/0-0-0-37501\#JD_18.80.060 [https://perma.cc [ZNY6-U7MB].

134. See Richard H. McAdams, The Origin, Development, and Regulation of Norms, 96 Mich. L. REV. 338, 355-72 (1997).

135. The advent of the internet has somewhat reduced housing consumers' costs of collective action. One outgrowth was the birth of the YIMBY (Yes In My Backyard) movement in the 2010s.

136. See Michael D. Gilbert, Campaign Finance Disclosure and the Information Tradeoff, 98 Iowa L. Rev. 1847, 1871 (2013). In California, these donations cannot be anonymous. See CAL. Gov'T CODE $\S \S 84211$ (f), 90008(a) (West, Westlaw through 2020 Legis. Sess.). On the merits of compelled disclosure, see Ian Ayres, Disclosure Versus Anonymity in Campaign Finance, in 42 Nomos, Designing Democratic Institutions 19 (Ian Shapiro \& Stephen Macedo eds., 2000).

137. See infra note 193. 


\section{B. Why Are Austin Suburbs Relatively Pro-Growth?}

The next three subsections strive to develop a theory of zoning politics that is consistent with the larger study's three principal empirical findings. The first is that localities in the northwest sector of Austin, in general, have been far more likely than those in Silicon Valley and Greater New Haven to allow multifamily housing and small-lot subdivisions, and to desist from large lot zoning. ${ }^{138}$ Why so?

Two possibilities stand out. ${ }^{139}$ The first, a stripped-down version of the growth machine theory, emphasizes the economic payoffs to housing suppliers when zoning is pro-growth. The relative inattention of voters to local politics eases the burden of putting together a pro-growth coalition capable of controlling city hall. Homebuilders obviously have a huge stake in zoning policy. But a wide variety of other specialists also profit from increased housing supply: construction workers; subcontractors; civil engineers; real estate brokers; real estate attorneys; mortgage lenders; owners and employees of restaurants, furniture stores, moving companies; and on and on. ${ }^{140} \mathrm{~A}$ fast-growing metropolis, by definition, has a larger number of these diverse suppliers, which increases their political heft. In all but the most elite suburbs, local political control may be within their reach. Where housing demand is strong, pro-growth policies thus may be politically self-perpetuating.

This stripped-down growth-machine conception also forecasts that the progrowth inclinations of Austin's suburbs might not endure. If national fertility rates and immigration rates were to plummet, housing development would slow, weakening the housing-supplier coalition nationwide. The defeat of CodeNEXT at the hands of NIMBYists suggests that politics in the Austin metro hardly lies beyond the national mainstream. ${ }^{141}$

A second theory of why municipalities in Greater Austin have been pro-growth stresses the political ideologies of both voters and elected officials. ${ }^{142}$ In contrast to the prior theory, this one implies that the Austin region's pro-growth policies might continue. The ideologies of the median Texas voter and legislator differ from their counterparts in both California and Connecticut. Academic economists, who devote their lives to the world of ideas, ironically have been resistant to the notion that ideas

138. See Ellickson, supra note 8 , at $12-31$ (describing zoning practices in these three metropolitan areas).

139. A third possibility is that Greater Austin's undeveloped land, on average, has less environmental value than land in the other two metros. If so, environmentalist opposition to housing development might be less intense. This is more plausible in the relatively flat portions of Greater Austin, such as Round Rock, than in, say, West Lake Hills.

140. "From 1960 until 1982 almost every member of the [Redwood City, California] City Council favored continued housing construction. Most council members have been employed in jobs related to the housing industry or in local Redwood City businesses which would benefit from growth." Stephen F. Cook, Redwood City: High Housing Prices and No Growth, 4 StAn. EnV'T L. ANN. 68, 71 (1982).

141. See supra text accompanying notes 67-69.

142. See Ideas and Politics in Social Science Research (Daniel Béland \& Robert Henry Cox eds., 2011); James Q. Wilson, How Divided Are We?, CommentaRy (Feb. 2006), https://www.commentarymagazine.com/articles/james-wilson/how-divided-are-we/ [https://perma.cc/TAJ2-PSKS]. 
matter. Some economic historians have begun to break ranks and to emphasize the power of ideas to shape events. ${ }^{143}$ In the context of land use regulation, several authors have noted the potential influence of political ideologies. ${ }^{144}$ Fischel has associated the rise of suburban growth controls with the rise of the environmental movement in the late 1960s. ${ }^{145}$ The chronology of Silicon Valley zoning politics firmly supports Fischel's thesis. ${ }^{146}$ And Matthew Kahn has found evidence that, controlling for other variables, California cities with more residents registered in leftleaning parties have been less likely to permit new housing development. ${ }^{147}$

Stereotypes and statistics both support the notion that Texans tend to favor a government that regulates less. Texas lawyers, for example, are notably more politically conservative than those in California and Connecticut. ${ }^{148}$ A predilection for small government likely boosts the popularity of pro-growth policies in Austin suburbs. When asked whether there was an anti-growth faction in Round Rock, Texas, a member of the city's planning staff stated that none existed. ${ }^{149}$ Self-selection by migrants may have contributed to this political tilt. Some observers surmise that adults are more likely to move to, and remain in, places where other people share their values. ${ }^{150}$ Households with relatively pro-growth inclinations may have been flocking to the Austin area. Even apart from ideology, a metro's growth history likely has some effect on who migrates there. A metro, such as Greater Austin, where some of the landscape is constantly changing, might put off a person harboring a strong status quo bias.

143. See, e.g., Deirdre Nansen McCloskey, Bourgeois Equality: How Ideas, Not Capital or Institutions, Enriched the World (2016); Joel Mokyr, A Culture of GROWTH: THE ORIGINS OF THE MODERN ECONOMY (2017).

144. See, e.g., Mark Baldassare \& Georjeanna Wilson, Changing Sources of Suburban Support for Local Growth Controls, 33 URB. STUD. 459 (1996) (emphasizing ideological inclinations).

145. William A. Fischel, Zoning Rules! The Economics of Land Use Regulation 203-05 (2015).

146. See Ellickson, supra note 8, at 32-33.

147. Matthew E. Kahn, Do Liberal Cities Limit New Housing Development? Evidence from California, 69 J. URB. ECON. 223 (2011).

148. See Adam Bonica, Adam S. Chilton \& Maya Sen, The Political Ideologies of American Lawyers, 8 J. LEGAL ANALYSIS 277, 299 (2016) (deriving ideologies from campaign contributions).

149. Interview with Clyde von Rosenberg, Senior Planner, City of Round Rock, Tex. (in Round Rock, Oct. 30, 2018).

150. See, e.g., Bill Bishop, The Big Sort: Why the Clustering of Like-Minded AMERICA Is TEARING Us ApART (2008); see also Jason Sorens, The Effects of Housing Supply Restrictions on Partisan Geography, 66 POL. GEOGRAPHy 44, 44 (2018) (finding that states and localities with more restrictive land use controls become more Democratic over time). But see Jonathan Mummolo \& Clayton Nall, Why Partisans Do Not Sort: The Constraints on Political Segregation, 79 J. PoL. 45, (2017). 


\section{Why Homeowners Typically Can Freeze Zoning, Even in Greater Austin}

Part I marshaled evidence that a straitjacket binds most established U.S. neighborhoods of single-family houses, even in Greater Austin. ${ }^{151}$ This section seeks to develop a theory of local zoning politics that is consistent with this finding. All politics, it is said, is local. The straitjacket thesis implies that zoning politics in fact is hyperlocal. It suggests that Palo Alto officials, if asked to consider a zoning proposal that would densify Professorville, would virtually always give priority to the wishes of incumbent Professorville homeowners. ${ }^{152}$

Fischel's homevoter hypothesis, which emphasizes homeowners' interests in maximizing their house values, offers a foundation on which to build a theory of hyperlocal zoning politics. Fischel's theory has the merit of parsimony, but some enrichments might enhance its descriptive power.

\section{Psychology: Status Quo Bias}

People are wary, an evolutionary trait that may be generally adaptive. As Laurence Siegel puts it, "Our neural network says to us all the time: That could be a tiger, or it could be a rabbit, so let's assume it's a tiger." 153 According to renowned cognitive psychologists Daniel Kahneman and Amos Tversky, individuals choose a reference point from which to evaluate the consequences of a change. From that reference point, they give more weight to losses than to objectively equivalent gains. ${ }^{154}$ Humans innately fear that change will bring tigers, not rabbits.

Status quo bias especially influences land use policy when, as is typical in the United States, a local government makes zoning decisions. ${ }^{155}$ Both local voters and local officials plainly choose the existing landscape as their reference point. ${ }^{156}$ This enhances the hyperlocal nature of zoning politics and fosters NIMBYism.

151. See supra text accompanying notes 66-77 (describing straitjacket in Austin).

152. See EINSTEIN ET AL., supra note 119, at 102-03 (finding that nearly half of all commentators at public zoning hearings lived on the same block where new housing was being proposed).

153. Jason Zweig, Why Invest? A 22-Year-Old's Tough Questions About Capitalism, WALl ST. J. (Jan. 24, 2020, 3:47 PM), https://www.wsj.com/articles/why-invest-a-22-year -olds-tough-questions-about-capitalism-11579882164? $\mathrm{mod}=$ searchresults \&page=1\&pos=1 [https://perma.cc/5H8B-BRTD].

154. See Daniel Kahneman \& Amos Tversky, Prospect Theory: An Analysis of Decision Under Risk, 47 EconometricA 263, 279 (1979); Daniel Kahneman, Jack L. Knetsch \& Richard H. Thaler, Anomalies: The Endowment Effect, Loss Aversion, and Status Quo Bias, 5 J. ECON. PERSPS. 193, 199 (1991). The Kahneman-Tversky theory has won wide acceptance. See Edward Glaeser, Triumph of the City: How Our Greatest Invention MaKes Us Richer, Smarter, Greener, Healthier, And Happier 262 (2011); Russell B. Korobkin \& Thomas S. Ulen, Law and Behavioral Science: Removing the Rationality Assumption from Law and Economics, 88 CALIF. L. Rev. 1051, 1104-13 (2000). But cf. Charles R. Plott \& Kathryn Zeiler, Exchange Asymmetries Incorrectly Interpreted as Evidence of Endowment Effect Theory and Prospect Theory?, 97 AM. EcON. REV. 1449 (2007).

155. See infra text accompanying notes $181-87$.

156. Several legal scholars have briefly discussed the possible influence of status quo bias on land use regulation. See Holly Doremus, Takings and Transitions, 19 J. LAND UsE \& ENV'T 
The residential densification of a neighborhood such as Professorville in Palo Alto would have both negative and positive neighborhood effects. The downsides might include more traffic, greater difficulty in finding empty parking spaces on the street, bulkier buildings that cast longer shadows, and greater risks in the event of a pandemic. Densification also would bring a variety of benefits. Some would be local, such as enhanced safety because of more pedestrian traffic and a potential increase in the variety and quality of nearby stores and restaurants. Other benefits would be diffuse, such as greater specialization of Silicon Valley job opportunities and an increase in networking opportunities. On account of status quo bias, Professorville residents would tend to give more weight to each of the various prospective costs than to each of the prospective benefits. ${ }^{157}$

A rezoning to permit the building of townhouses or low-rise apartments on Professorville lots might triple the market value of the rezoned lots. ${ }^{158}$ In an extreme case, notably near a new transit node, prospects for reaping these financial gains might induce some homeowners to favor densification. ${ }^{159}$ Status quo bias, however, limits the likelihood of this result. On account of the bias that Kahneman and Tversky assert, Professorville homeowners likely would undervalue the windfalls they would gain from rezonings. ${ }^{160}$

Status quo bias powerfully affects land use politics across the board. For starters, it supports the perpetuation of existing uses. Illustrative is the widespread municipal practice of permitting nonconforming uses to remain even when they nominally violate current zoning mandates. ${ }^{161}$ Conversely, status quo bias stirs up resistance to new land uses. It undergirds NIMBYist opposition to change near one's backyard. ${ }^{162}$

L. 1, 21-24 (2003); David B. Spence, The Political Economy of Local Vetoes, 93 TEX. L. ReV. 351, 396-97 (2014).

157. On the actual arguments used by opponents of proposed housing developments, see EINSTEIN ET AL., supra note 119, at 87-88, 115-145, and Rolf Pendall, Opposition to Housing: NIMBY and Beyond, 35 Urb. Afrs. Rev. 112 (1999). On objections to subsidized housing projects in particular, see Mai Thi Nguyen, Victoria Basolo \& Abhishek Tiwari, Opposition to Affordable Housing in the USA: Debate Framing and the Responses of Local Actors, 30 HOUS., THEORY \& SOC'Y 107 (2013).

158. See supra text accompanying note 80 .

159. See supra text accompanying notes 78-93.

160. Fischel has proposed creation of a market for home-value insurance. FisCHEL, supra note 118 , at $8-10,268-70$. If NIMBYist fears of worst-case outcomes arise from psychological predispositions, however, and not from rational responses to risk, this innovation would be less than completely effectual.

161. Especially in older cities, many existing residential buildings violate current zoning requirements. In Somerville, Massachusetts, a city whose population is nearly 80,000, one study found that only twenty-two residential uses conformed to all current zoning requirements. Daniel Hertz, The Illegal City of Somerville, City OBSERvatory: COMMENTARY (June 15, 2016), http://cityobservatory.org/the-illegal-city-of-somerville/ [https://perma.cc/6V5Y-HTX2]. Connecticut flatly forbids its local governments from amortizing (phasing out) nonconforming uses. ConN. Gen. STAT. § 8-2 (2020), https://www.cga.ct.gov/current/pub/chap_124.htm\#sec_8-2 [https://perma.cc/9L3Z-EJ33].

162. See, e.g., Barak D. Richman \& Christopher Boerner, A Transaction Cost Economizing Approach to Regulation: Understanding the NIMBY Problem and Improving Regulatory Responses, 23 Yale J. on Regul. 29 (2006). On the psychology of NIMBYism, see, for 
It helps account for opposition to the gentrification of neighborhoods. ${ }^{163}$ It finds expression in assertions of the importance of preserving "community character."164 It lies at the heart of the precautionary principle, a credo of environmentalists reluctant to encounter new risks. ${ }^{165}$ It spurs popular support for preventing development of existing open spaces. ${ }^{166}$

Status quo bias also generates political support for historic preservation, a cause commonly worthy, if hardly without costs. ${ }^{167}$ Around the world, central cities have led efforts to preserve both landmarks and historic neighborhoods. French lawmakers have, as Alain Bertaud has perceptively asserted, sought to maintain "Paris streets as they were at the time of the Impressionists." 168 During the nineteenth century, Manhattan was one of the most dynamic U.S. real estate markets, perhaps overly so. The dynamism led to the razing of many buildings worthy of preservation. ${ }^{169}$ Today, by contrast, the city's real estate is overly static. Too many Manhattan structures are frozen in historic districts, and New York City zoning procedures tend to favor NIMBYists. ${ }^{170}$

The psychological disposition to favor the perpetuation of the familiar extends to most features of the existing visual environment. Many localities that would never approve construction of a new neon sign or billboard, for example, strive to preserve an old and familiar one. Notable examples are the CITGO sign adjacent to Fenway Park in Boston, and the Hollywood sign high in the Los Angeles hills. Palo Alto, a

example, Patrick Devine-Wright, Rethinking NIMBYism: The Role of Place Attachment and Place Identity in Explaining Place-Protective Action, 19 J. CMTY. \& APPLIED Soc. Psych. 426 (2009). One national survey has found that respondents, by a margin of $52 \%$ to $36 \%$, favored maintaining, rather than relaxing, zoning restrictions on housing production. HART RSCH. Ass'N., MacArthur How Housing MATters Survey \#11127 8 (Apr. 2014).

163. See, e.g., Jon C. Dubin, From Junkyards to Gentrification: Explicating a Right to Protective Zoning in Low-Income Communities of Color, 77 MINN. L. REv. 739 (1993).

164. Courts have frequently ruled on whether a suburb's use of zoning to protect the existing character of a neighborhood is a legitimate exercise of the police power. The supreme courts of California, Connecticut, and Texas, the states that contain the three metros studied, all have held that it is. See Miller v. Bd. of Pub. Works, 234 P. 381, 386-88 (Cal. 1925); Damick v. Planning \& Zoning Comm'n, 256 A.2d 428, 431 (Conn. 1969); Mayhew v. Town of Sunnyvale, 964 S.W.2d 922, 934-35 (Tex. 1998).

165. See Cass R. Sunstein, Beyond the Precautionary Principle, 151 U. PA. L. Rev. 1003, 1003 (2003) (warning of principle's potential paralyzing effect).

166. See Ellickson, supra note 8, at 59-63.

167. See, e.g., Ingrid Gould Ellen \& Brian J. McCabe, Balancing the Costs and Benefits of Historic Preservation, in Evidence AND InNOvation In Housing LAW AND Policy 87 (Lee Anne Fennell \& Benjamin J. Keys eds., 2017) (recognizing benefits of preservation efforts, but urging attention to associated costs); Edward L. Glaeser, Preservation Follies: Excessive Landmarking Threatens to Make Manhattan a Refuge for the Rich, CiтY J. 62, Spring 2010, https://www.city-journal.org/html/preservation-follies-13279.html [https://perma.cc/HVY8 -HH7U].

168. Alain Bertaud, Order Without Design: How Markets Shape Cities 314 (2018).

169. See infra text accompanying note 198 .

170. See, e.g., Been et al., supra note 78; Glaeser, supra note 167; Schleicher, supra note 101 , at $1695-98$. 
municipality hardly likely to permit the opening of a new mobile home park, is making strenuous efforts to prevent the closing of an existing one. ${ }^{171}$

The straitjacket hypothesis explicitly supposes that a proposal to densify would encounter more opposition in a neighborhood of detached houses than in one that includes duplexes, townhouses, and apartment buildings. ${ }^{172}$ Some evidence is supportive. In the Bay Area, it is significant that the "grand bargain" permits residential densification only in neighborhoods where house owners are few. ${ }^{173}$ And Eric Steele has observed that Evanston, Illinois, was particularly solicitous of protecting its single-family neighborhoods:

Community opposition is a more potent force than is community support, and both are more powerful in the context of a single-family neighborhood. This conclusion is consistent with what we have seen to be the central impulse of urban zoning - conserving the character of existing residential areas, particularly single-family neighborhoods. ${ }^{174}$

In neighborhoods where residential densities are greater, exclusionary practices are hardly unknown, but they appear to surface less powerfully and pervasively. ${ }^{175}$

Neighborhood opposition to change may deepen with a homeowner's duration of ownership, age of neighborhood, and perhaps even the age of a zoning government. ${ }^{176}$ Mancur Olson has asserted that age causes institutions to become more rigid. ${ }^{177}$ In the three metros studied, New Haven's suburbs are by far the longest settled. They also have existed the longest as municipalities, and none of their boundaries has changed since $1921 .{ }^{178}$ These forms of seniority conceivably have

171. Buena Vista, Palo Alto's sole mobile home park, is located a few steps away from El Camino Real. It dates back at least to the 1940s. In the 2010s, the park's owner sought to close the park. In 2017, after lengthy negotiations, Palo Alto and two other public agencies agreed to buy the facility for $\$ 400,000$ per space. They plan eventually to replace Buena Vista with subsidized housing affordable to its former residents. Eric Kurhi, $\$ 40$ Million Purchase Saves Palo Alto's Buena Vista Mobile Home Park, Mercury News (May 19, 2017, 7:44 AM), http://www.mercurynews.com/2017/05/18/a-great-great-day-palo-altos-buena-vista-mobile -home-park-is-saved/ [https://perma.cc/5XK8-KZEB].

172. See supra text accompanying notes $18-19$.

173. O'Neill, supra note 46, at 68.

174. Steele, supra note 78 , at 731.

175. See Edward L. Glaeser \& Bryce A. Ward, The Causes and Consequences of Land Use Regulation: Evidence from Greater Boston, 65 J. URB. ECON. 265, 266-67 (2009) (asserting that a locality where housing density has historically been high appears to be less likely to embrace exclusionary practices).

176. Michal A. Strahilevitz \& George Loewenstein, The Effect of Ownership History on the Valuation of Objects, 25 J. CONSUMER RES. 276 (1998), is the leading study of the effect of length of ownership on perceptions of loss. The authors found that those who owned an item of personal property for up to an hour valued it more highly than those just given it. Owners of real estate might behave differently.

177. See Mancur Olson, The Rise and Decline of Nations: Economic Growth, Stagflation, And Social Rigidities (1982).

178. Ellickson, supra note 8, at 53. 
contributed to New Haven suburbanites' exceptional hostility to both multifamily housing and small house lots.

Social scientists, including psychologists, have seldom explored the ramifications of status quo bias in the land use arena. ${ }^{179}$ On its face, the bias leads to normatively myopic results. After a new land use has replaced an old one, local residents likely would soon regard the new use to be part of the status quo. Manhattanites may now be fully acclimated to the Freedom Tower, one of the skyscrapers that replaced the World Trade Center towers destroyed on September 11, 2001. If most individuals indeed do adapt quickly to the advent of new structures, policymakers perhaps should give less weight to prospective fears of neighborhood change. ${ }^{180}$

Interest in preserving an existing landscape appears to be more salient to local officials than to either state or federal officials, perhaps because local officials are closer to the landscape at hand. Local governments vary in many dimensions. When city council members are elected by district, as opposed to at-large, researchers have found that they are particularly inclined to protect the status quo. ${ }^{181}$ Even a populous local government is likely to treat a zoning decision as hyperlocal. In 2010, both San Mateo and Santa Clara Counties in Silicon Valley had populations over 700,000. Yet, when zoning their scattered pockets of unincorporated land, officials of both counties seem to give special weight to the tastes of voters residing near the site in question. San Mateo County requires in North Fair Oaks, a blue-collar area in its plains, a mere $5 \mathrm{k}(5,000$ sq. ft.) house-lot. The County's required minimum in Emerald Lake Hills, an unincorporated area in the foothills, however, is $12 \mathrm{k}$, a requirement in line with the zoning policies of surrounding suburbs. Santa Clara County similarly requires $5 \mathrm{k}$ lots in Burbank, a blue-collar area in its plains, but $20 \mathrm{k}$ lots in Loyola, which lies in the foothills. On Stanford lands, Santa Clara County requires a 20 -acre house-lot. ${ }^{182}$ These varying requirements grow out of differences in not only site characteristics, but also the hyperlocal dynamics of local zoning politics.

Status quo bias appears to affect the land use policies of local officials more greatly than the policies of state or national officials. Officials of a higher-level government generally are more disposed to support change. Oregon, for example, has compelled its localities to abolish their single-family zones, and many states require localities to accommodate group homes and other controversial uses. ${ }^{183}$ The federal government puts pressure on localities to accept religious land uses, cellphone towers, and other uses. ${ }^{184}$ In France and Japan, national governments largely control land use policy. France flatly forbids its local governments from setting

179. An exception is Patrick Devine-Wright. See Devine-Wright, supra note 162.

180. Cf. Cass R. Sunstein, Back to Mill? Behavioral Welfare Economics (Apr. 14, 2020) (unpublished manuscript) (on file with Harvard Law School) (exploring implications of behavioral realities for policymaking).

181. See supra notes 103-04 and accompanying text.

182. Ellickson, supra note 8 , at 40 .

183. See supra note 100; Lemar, supra note 106.

184. See supra note 106; Telecommunications Act of 1996, 47 U.S.C. $§ 332(C)(7)(2012)$. 
minimum sizes for house-lots. ${ }^{185}$ Japan's policies have enabled the building of highrise apartments in Tokyo. ${ }^{186}$ The United States has followed a different path. State governments, in the early twentieth century, decided to authorize local governments to largely shape zoning policy. ${ }^{187}$ This momentous choice greatly enhanced the influence of status quo bias and, by extension, the power of NIMBYist forces.

\section{Sociology: Esteem and Disesteem in the Eyes of Neighbors}

Sociologists could fruitfully analyze how homeowners in neighborhoods of houses react to proposals that threaten densification. Most homeowners have social ties, some strong, some weak, with neighbors. ${ }^{188}$ Parents of children long enrolled in local public schools are likely to be especially socially enmeshed. Residents with the strongest and most irreplaceable neighborhood ties likely would be the most fervent opponents of densification. At a public hearing, they would be prime candidates for assuming the role of "neighborhood defender," to invoke Einstein, Glick, and Palmer's apt phrase. ${ }^{189}$ A key sociological question is whether other neighbors would confer esteem, or disesteem, on those who had stepped into that role. ${ }^{190}$ The existence of the zoning strait jacket suggests the usual answer: esteem.

The possibility of financial profit, however, complicates densification scenarios and heightens their sociological interest. As noted, in a neighborhood such as Professorville, the owner of a lot rezoned for higher density might benefit from a huge increase in the lot's market value. ${ }^{191}$ That prospect might induce some of them to act, not as neighborhood defenders, but as pro-densification profit maximizers. A better understanding of these social dynamics would be enlightening.

\section{Norms of Distributive Justice}

Communication specialists, and ethicists who concern themselves with the fairness of rewards, also may have something to contribute to the understanding of zoning politics. The beneficiaries of residential densification would include, among many others, housing consumers and construction workers. Opponents of a densification measure, however, would be wise to characterize the sole prospective beneficiaries as greedy developers. ${ }^{192}$ Monkkonen and Manville have found that this

185. COde De L'URBANISME, § 123-1-5 (2019), as amended by loi ALUR (2014). See Rozen Noguellou, La règle d'urbanisme et les PLU-Où se trouve la règle d'urbanisme? REVUE FRANÇAISE DE DROIT ADMINISTRATIF 872 (Sept.-Oct. 2016).

186. André Sorensen, Junichiro Okata \& Sayaka Fujii, Urban Renaissance as Intensification: Building Regulation and the Rescaling of Place Governance in Tokyo's Highrise Manshon Boom, 47 URB. STUD. 556 (2010).

187. See Ellickson, supra note 8, at 97.

188. See Claude S. Fischer, To Dwell Among Friends: Personal Networks in Town and City (1982); Herbert J. Gans, The Levittowners: Ways of Life and Politics in A New Suburban COMmunity (1967).

189. See EInSteIn ET AL., supra note 124.

190. See McAdams, supra note 134.

191. See supra text accompanying notes $158-60$.

192. This perception might have startled Joseph Eichler. Eichler Homes filed for 
framing, with its implication of ill-gotten gains, tends to bolster public opposition to development proposals. ${ }^{193}$ The fate of zoning proposals to bring greater urban density may turn on perceptions of who would benefit. YIMBYs (Yes In My Backyard advocates) should take note.

Fischel's homevoters are subject to the usual human frailties. They are likely to give more weight to prospective losses from densification than to prospective gains. Few are immune to the social pressures of neighbors, or to claims of excessive developer profits. Developers of denser forms of housing are aware of these realities. They typically decide that their best targets of opportunity lie not in neighborhoods where detached houses predominate, but elsewhere.

\section{Proximity to a Transit Node May Flip Zoning Politics Toward Densification}

Of this study's central findings, economists are apt to find this one easiest to understand. The opening of the Courthouse Metro station in Arlington, Virginia, promised to bring financial riches to owners of houses located nearby. To cash in, these homeowners eventually supported the densification of their neighborhood, and county officials duly removed the single-family straitjacket. ${ }^{194}$

Why does zoning politics in a neighborhood such as Professorville-indeed, in any of Palo Alto's many single-family neighborhoods - operate so differently? The work of Kahneman and Tversky currently provides the most penetrating insight. ${ }^{195}$ Status quo bias systematically influences these homeowners. It makes them undervalue all types of gains, including financial gains, that they would obtain from rezonings for greater density. The upshot, in too many cases, is rampant NIMBYism.

\section{CONCLUSION}

In the United States, local zoning politics freezes land uses in neighborhoods of detached houses. This is true not only in wealthy suburbs, such as Palo Alto, Woodbridge, and West Lake Hills, but also in Euclid, whose median household income is $25 \%$ of Palo Alto's. ${ }^{196}$ Homeowners in these neighborhoods, of course, commonly are free to raze their houses and replace them. But, with rare exception, local zoning rules forbid construction of denser residential structures, even duplexes. This zoning straitjacket binds a solid majority of the nation's urbanized land. In the eyes of most urban officials, the American Dream of homeownership can only be fulfilled in a neighborhood of detached houses. Other developed nations, such as

bankruptcy in 1967. See Joseph Eichler, WIKIPEDIA, https://en.wikipedia.org/wiki/Joseph _Eichler [https://perma.cc/VUG8-XZSP].

193. Paavo Monkkonen \& Michael Manville, Opposition to Development or Opposition to Developers? Experimental Evidence on Attitudes Towards New Housing, 41 J. Urb. AfFs. 1123 (2019) (finding that a survey frame that highlighted developers' profits increased project opposition by $20 \%$, twice the increase of a frame that highlighted traffic-congestion issues).

194. See supra text accompanying notes 79-80.

195. See supra note 154 and accompanying text.

196. See supra note 97. 
England, France, Germany, and Japan, have policies that are more tolerant of denser forms of residential living. ${ }^{197}$

The rigidity of the zoning straitjacket inflicts major costs on the United States. Real estate and labor markets, if freer to operate, would enable the nation to adjust to the inevitable changes over time in supply and demand conditions. During the nineteenth century, the Manhattan real estate market may have been overly dynamic. Federal Hall, the site of George Washington's initial inauguration, was arguably the nation's most historic building when it was razed in $1812 .{ }^{198}$ Today, the problem is not excessive dynamism, but excessive stasis. In the words of the immortal Jane Jacobs, "The purpose of zoning . . . should not be to freeze conditions and uses as they stand. That would be death." $" 199$ Homeowners in neighborhoods of detached houses have learned how to do exactly what Jacobs dreaded. Life is better.

197. The literature on comparative land use policy understandably is thin. High-quality comparative work requires a deep knowledge of the cultures and institutions of the examined nations.

198. John Tauranac, Lost New York, Found in Architecture's Crannies, N.Y. Times (Feb. 12, 1999), https://www.nytimes.com/1999/02/12/arts/lost-new-york-found-in-architecture-s -crannies.html [https://perma.cc/7SQB-DT6L].

199. JACOBS, supra note 6, at 253. But cf. Naomi Schoenbaum, Stuck or Rooted? The Costs of Mobility and the Value of Place, 127 YALE L.J.F. 458 (2017) (stressing the benefits of rootedness). 